2

3 (a) Title:

4 Asymmetric ice-sheet retreat pattern around northern Scotland revealed by

5 marine geophysical surveys

6

7 (b) Authors:

8 Tom Bradwell, Martyn Stoker

9

10 (c) Authors' address:

11 British Geological Survey, Murchison House, West Mains Road, EH9 3LA, UK

12

13 (d) Running Head:

14 Ice sheet retreat around Northern Scotland

15

16

17

18

19

20

21

22

23

24

25

26

27 


\section{Asymmetric ice-sheet retreat pattern around northern Scotland revealed by 2 marine geophysical surveys}

\section{Abstract}

This study uses marine geophysical data, principally singlebeam and high-resolution multibeam echosounder bathymetry, combined with seismic sub-bottom profiles, and existing Quaternary geological information, to map the glacial geomorphology of a large area of seafloor $\left(\sim 50,000 \mathrm{~km}^{2}\right)$ on the continental shelf around northern Scotland, from west of Lewis to north of the Orkney Islands. Our new mapping reveals the detailed pattern of submarine glacial landforms, predominantly moraines, relating to ice sheets that covered Scotland and much of the continental shelf during the Late Weichselian glaciation and earlier in the Mid to Late Pleistocene. The reconstructed retreat pattern based on geomorphological evidence highlights the large number of different retreat stages and the asymmetric, non-uniform evolution of this ice sheet sector during Late Weichselian deglaciation. Time-equivalent ice-front reconstructions show that marine sectors of the ice sheet, such as the Minch, changed their geometry significantly, perhaps rapidly; whilst other sectors remained relatively unchanged and stable. We suggest that this behaviour, governed principally by bed topography/bathymetry and ice dynamics, led to re-organization of the Late Weichselian ice sheet as it retreated back to two main ice centres: one in Western Scotland and the other over Orkney and Shetland. This retreat pattern suggests relatively early deglaciation of NW Lewis (ca. $25 \mathrm{ka}$ BP) and the mountains of far NW Scotland - the latter possibly forming a substantial ice-free land corridor. Our reconstructions differ from most previous syntheses, but are strongly supported by the independently mapped offshore Quaternary succession and key onshore dating constraints.

Key words 
1 The rate and style of contemporary ice sheet retreat relates to a number of globally important scientific and socio-economic questions (IPCC, 2013). Mapping and dating ice-sheet retreat, both past and present, improves our understanding of how large ice masses dynamically respond to internal and external forcing, such as glaciological, climatic and sea level perturbations. In turn, this information can be used to better predict how present-day ice sheets will respond under future different climatic and sea level scenarios. The former British-Irish Ice Sheet (BIIS) during the last glacial cycle provides a relatively small but geospatially well constrained example of a mid-latitude marine-influenced ice sheet which at its maximum was around one third the size of the present-day West Antarctic Ice Sheet, or approximately equivalent to $\sim 2 \mathrm{~m}$ of eustatic (global) sea level change (Hubbard et al., 2009; Gibbard \& Clark, 2011; Clark et al., 2012).

Although well studied, with over 100 years of literature on the topic, the geometry of the BIIS and its deglaciation pattern in certain key sectors between the Last Glacial Maximum (LGM: ca. 25-30 ka BP) and Greenland Stadial 1 (13-11.5 ka BP) are still uncertain (e.g. Sutherland, 1984; Gordon \& Sutherland, 1993; Evans et al., 2005; Chiverrell \& Thomas, 2010). An insight into the distribution and complexity of the Quaternary stratigraphic succession on the continental shelf to the north and west of Scotland, as well as tentative ice limits, was established in the early 1990s as part of the BGS regional offshore mapping programme of the UK Continental Shelf (Fyfe et al., 1993; Stoker et al., 1993). The resultant stratigraphic framework was based upon a combination of geophysical data (seismic-reflection profiles), geological boreholes and shallow core material. The recent acquisition of seabed imagery - combined with the legacy geophysical and geological datasets - has shed important new light on the offshore extent and general retreat pattern of the ice sheet especially in its northern and western sectors (Bradwell et al., 2008a; Dunlop et al., 2010; Stoker and Varming 2011, O Cofaigh et al., 2012; Howe et al., 2012; Stoker, 2013). Collation of the pre-existing landform evidence (Clark et al., 2004) and dating constraints (Hughes et al., 2011) with new bedform mapping across the British (Hughes et al., 2010) and Irish landmasses (Greenwood \& Clark, 2009), and the offshore landform evidence (Bradwell et al., 2008a) as well as some additional mapping, allowed Clark et al. (2012) to produce an empirically based ice-sheet-wide reconstruction, with time slices showing key stages of retreat. Their work is currently the best available synthesis of the geomorphological evidence relating to the last BIIS, but is still only a generalised picture owing to the low-resolution and variable coverage quality of the offshore datasets used.

In this paper we present a refinement of this picture for the NW sector. We use recently acquired marine geophysical data, in the form of both singlebeam and multibeam echosounder, alongside 
character of seabed features relating to the ice sheet that once covered northern Scotland. The seabed glacial geomorphology is described and then interpreted - using geomorphological principles, established landsystem models and reference to other published geological data - to reconstruct a detailed and glaciologically plausible pattern of ice sheet retreat from the continental shelf edge to the Scottish mainland. The resulting pattern differs from previous mapping, including the interpretations presented by Bradwell et al. (2008a) and Clark et al. (2012), and opens up questions about the style and retreat dynamics of deglaciation around northern Scotland and, by implication, the palaeo-glaciology and palaeo-environment of the wider region.

\section{Study Area}

\subsection{Geographical extent}

We focus on an area of the UK continental shelf around northern Scotland, where bathymetric data coverage is exceptionally good and the Pleistocene seabed geomorphology is remarkably well preserved. Specifically, the area comprises all the continental shelf within a box $310 \mathrm{~km} \mathrm{~N}-\mathrm{S}$ by 330 $\mathrm{km} \mathrm{E}-\mathrm{W}$, approximately centred on $59^{\circ} \mathrm{N}, 5^{\circ} \mathrm{W}$ (Fig. 1). The westward extent of the continental shelf is defined by the shelfbreak, in this study approximated by the present-day $200 \mathrm{~m}$ water depth contour. The study area also includes part of the mainland of Scotland, north of Loch Ewe, as well as the islands of Orkney, Lewis and the small outlying islands and rocks of North Rona, Sula Sgeir and Sule Skerry - although no onshore data has been analyzed in this study. The total area of continental shelf seabed within the study is ca. $55,000 \mathrm{~km}^{2}$, of which $>90 \%$ is covered by singlebeam bathymetry data and $\sim 45 \%$ is covered by recently acquired high-resolution multibeam data (Fig. 2).

\subsection{Quaternary geology and glacial history}

The Quaternary deposits and stratigraphy of the NW UK continental shelf are complex and difficult to correlate across the whole region, largely owing to their irregular and patchy nature, and the lack of well dated units. Stoker et al. (1993) summarised the Quaternary succession on the Hebrides and West Shetland shelves based on numerous seismic reflection profiles, geological boreholes, and other marine geophysical data collected by the BGS between the late 1960s and 1990 (Fig. 3). The regional development of the Quaternary succession presented by Stoker et al. (1993) has since been updated and summarised for both the Hebrides (Stoker, 2013) and West Shetland (Stoker and Varming, 2011) regions, and work continues in order to rationalise the Quaternary stratigraphy 
1 (Stoker et al., 2011a, b) as a basis to providing stratigraphic and geological context for seabed geomorphological mapping studies and palaeo-environmental (palaeo-glaciological) reconstructions.

Generally speaking, the Plio-Pleistocene deposits on the Hebrides Shelf, north of the Outer Hebrides, are thinner and less common than on shelf areas further south (e.g. Malin Shelf) and in the North Sea sector. Seismic profiles from the northern Hebrides Shelf show an irregular glacial unconformity, with overdeepened basins, cut into Mesozoic and Cenozoic strata, punctuated by locally upstanding remnants of Pre-Cambrian basement rocks (e.g. Sula Sgeir High). It is in the deeper basins where locally thick accumulations of Pleistocene sediments are preserved. Seismic records and boreholes identify subglacial, ice contact (morainic), and proglacial (outwash) sediments overlain by glaciomarine sediments within the main depocentres - the North Minch and North Lewis basins where the Quaternary sequence exceeds $100 \mathrm{~m}$ in places (Fyfe et al., 1993; Stoker et al., 1993; Stoker, 2013). These two large broad basins demarcate a wide bathymetric pathway, or cross-shelf trough, which terminates on the continental slope, where in excess of $200 \mathrm{~m}$ of Middle-Upper Pleistocene glacially influenced sediments have accumulated on the Sula Sgeir Fan (Stoker, 1995) (Figs. 1, 4). The location of this trough-mouth fan, in association with numerous diagnostic geomorphological criteria onshore and offshore, led to the identification of a palaeo-ice stream in this sector of the British-Irish ice sheet (Stoker and Bradwell, 2005; Bradwell et al., 2007). It is thought that the Minch ice stream was a quasi-stable glaciological feature draining ca. 10,000$15,000 \mathrm{~km}^{2}$ of the BIIS via a convergent system of fast-flowing tributaries (Bradwell et al., 2007; Bradwell, 2013); and was periodically active over the last 0.5 million years (Stoker and Bradwell, 2005; Stoker 2013)

Further north, the West Shetland Shelf has a generally similar Quaternary sediment architecture and glacial history to the Hebrides Shelf further south (Stoker 1995; Stoker and Varming, 2011). However, the mid-shelf is characterised by a number of thick partially overlapping diamictondominated sediment sequences forming moraine banks 30-50 m high and 3-6 km wide. Acoustically well-layered ponded sediments, proved in cores to be glaciomarine sandy muds, occur between the ridges. These large submarine moraines (or morainal banks), preserved on the seabed, are interpreted to mark sequential stillstands or ice-front oscillations during overall south-eastward retreat of the ice sheet across the shelf (Stoker and Holmes, 1991; Bradwell et al., 2008a). Micropalaeontological data from shallow cores in the uppermost glacial diamicton suggest deposition in water depths of less than $50 \mathrm{~m}$ (Stoker et al., 1993; Stoker and Varming, 2011). The whole moraine complex, termed the Otter Bank Formation (Fig. 3, 4), has been shown from seismostratigraphic correlations to be Late Weichselian (= Late Devensian) in age although the 
sediments themselves remain undated (Stoker and Holmes, 1991). Importantly, this moraine system is clearly visible on the singlebeam bathymetry NW of Orkney. The outer shelf and slope are characterised by a thick wedge of Plio-Pleistocene sediments with prograding and aggrading geometries. The uppermost semi-continuous ice-proximal debris-flow-dominated deposit forms the Rona and Foula Wedges - interpreted as large coalescent glacigenic sediment fans fed by an ice sheet margin reaching the shelf-edge west of Orkney and Shetland (Stoker 1995; Davison, 2005; Stoker and Varming, 2011).

Close to the shelf edge, adjacent to the Sula Sgeir Fan large broad sediment ridges with icebergscoured surfaces have been mapped from seismic data as submarine moraine banks (Stoker, 1990, 2013; Stoker \& Holmes, 1991) and stratigraphically defined as the MacDonald Formation (Stoker et al., 1993; Stoker et al., 2011a). The largest of these MacDonald Formation moraines occurs at the shelf edge in present-day water depths of $\sim 200 \mathrm{~m}$; it is a $20-30 \mathrm{~m}$ high ridge, up to $4 \mathrm{~km}$ wide with low angle slopes, and extending laterally for $50 \mathrm{~km}$. BGS seismic profiles show an acoustically structureless unit makes up the bulk of the ridge, probably a glacial diamicton, although the icedistal slope interdigitates with gently dipping accoustically layered units comprising the glacigenic slope apron on the upper Sula Sgeir Fan (Stoker, 1990, 1995, 2013; Stoker et al., 1993) (Fig. 4). The overall geometry and seismic character of the largest Macdonald Formation Moraine is similar to subaqueous grounding zone features (wedges and morainal banks) seen elsewhere in glaciated shelf settings (e.g. Shaw et al., 2006; Dowdeswell et al., 2008; Rydningen et al., 2013). This large moraine is also visible in singlebeam echosounder bathymetry data. The MacDonald Formation moraines were taken as evidence of widespread glaciation on the Hebrides Shelf during the Late Pleistocene (Stoker and Holmes, 1991; Stoker et al., 1993, 1994). However, a more precise age and their relationship with seabed moraines to the north and south remain unclear, though seismicstratigraphic evidence indicates that their deposition pre-dates the moraines of the Otter Bank Formation, which rest with angular discordance on the MacDonald Formation (Stoker and Holmes, 1991; Stoker et al., 1993). Despite this stratigraphic discordance, subsequent large-scale shelf-wide seabed geomorphological mapping and the resulting reconstructions have tentatively correlated these outer Hebrides Shelf moraines with others on outer West Shetland Shelf, 150 km to the NE (Bradwell et al., 2008a; Thomas and Chiverrell, 2010; Clark et al., 2012). Clearly, on the basis of seabed imagery alone, the stratigraphic and chronological basis for these correlations remains ambiguous. 


\subsection{Sea level history}

2 Whether or not the last British-Irish ice sheet had large marine sectors, grounded below sea level, during deglaciation is currently a topic of key interest (cf. Clark et al., 2012 Chiverrell et al., 2013;

4 Finlayson et al., 2014); one which impacts strongly on the style and dynamics of ice sheet retreat 5 (e.g. Alley et al., 2005; Schoof, 2012). At the time of Last Glacial Maximum, when Scotland was covered by a Late Weichselian ice sheet, global eustatic sea level was around 110-130 m below present (Lambeck, 1991, 1993; Peltier and Fairbanks, 2006). The relative sea level picture at this time offshore western Scotland was complex and is not well constrained on the NW continental shelf, but would have varied with distance from the main area of isostatic depression (Lambeck, 1993; Gordon and Sutherland, 1993). The apparent absence of raised marine (MIS 2) shorelines in the Outer Hebrides (Dawson, 1984) indicates that sea levels were probably lower than today at icefree times during much of the last glacial cycle. Numerical glacial rebound models predict that the Isle of Lewis and the adjacent Hebrides Shelf have experienced relative sea levels below that of the present day since c. 16 ka BP and probably since the global sea level minima ( 26 ka BP) (Lambeck, 1991, 1993; Milne et al., 2006). Northern hemisphere ice sheet deglaciation produced rapidly rising eustatic sea levels between 14-8 ka BP, however there is no evidence for raised sea levels in the Outer Hebrides even during the Holocene, suggesting that local crustal isostatic depression was great enough to more than offset eustatic sea level changes in the peripheries of NW Scotland. A similar setting is envisaged in Shetland where no raised shorelines have been identified (Sissons, 1987) and relative sea levels are thought to have risen continuously (if not smoothly) from deglaciation to the present day (Lambeck, 1991; Shennan et al., 2006). During Late Weichselian ice sheet deglaciation ( 18-16 ka BP), modelled seawater depths across much of the continental shelf around northern Scotland, between the Flannan Isles and Shetland, were 40 to $80 \mathrm{~m}$ lower than the present day (Lambeck, 1991, 1993). However, as previously mentioned this sea level scenario varied considerably with distance away from the centre of isostatic depression, with contemporaneous relative sea level at the coastline (Cape Wrath, 18-16 ka BP) being at or around the present-day marine limit; whilst $180 \mathrm{~km}$ further $\mathrm{S}$ in Skye and Arisaig, nearer the maximum isostatic depression, relative sea levels were probably $20-40 \mathrm{~m}$ higher than present during the same time period (Lambeck, 1991; Shennan et al., 2006). 


\section{Methods}

2 Shelf-wide singlebeam echosounder bathymetric datasets were used in conjunction with high-

3 resolution multibeam data to map the glacial geomorphology of a large area (c. 50,000 $\mathrm{km}^{2}$ ) of the

4 UK continental shelf. The singlebeam echosounder data is part of a global dataset, managed and 5 compiled by Olex AS (Trondheim) and licensed for scientific research. The multibeam echosounder 6 data was collected between 2006-2012 by various survey vessels under contract to the Maritime \& 7 Coastguard Agency (MCA), and forms part of an ongoing UK-wide bathymetric survey programme 8 conducted on behalf of the UK Hydrographic Office (UKHO). Both datasets use global navigation 9 satellite systems (GNSS) for geo-spatial positioning. The singlebeam data has a positional accuracy of $10 \mathrm{~m}$ or less; vertical resolution ranges from 0.1 to $1 \mathrm{~m}$. The dataset is more robust where multiple soundings have been conducted in the same area. Bathymetric surfaces can only be viewed and exported using the bespoke software which operates in Linux. The multibeam data is collected to UKHO survey standard using high-precision GNSS data and has a positional accuracy of $<0.5 \mathrm{~m}$ in $\mathrm{xyz}$ and a resolution of $<1 \mathrm{~m}$. The final output data is made available at $5 \mathrm{~m}$ resolution. The bathymetric data were processed and gridded at the British Geological Survey. Data manipulation and visualisation were conducted in Fledermaus software, allowing full 3-D visualisation and enhancement of bathymetric surfaces. High resolution geotiffs of the surface elevation data layers were imported into ArcGIS 10.1 where geomorphological features were digitising manually using bathymetric hillshade and slope models to aid accuracy. Specific details relating to geophysical data acquisition are not detailed here but are available in the Reports of Survey, available on request from MCA/UKHO or BGS/NERC.

\section{Results}

\subsection{Seabed geomorphology}

The digital bathymetric datasets around northern Scotland reveal well-preserved suites of seabed landforms covering large parts of the continental shelf (Figs. 5, 6). This section systematically describes the geomorphology of these landforms, principally their 3-D shape and spatial relationship with other features. Where possible these descriptions incorporate other published and unpublished geological information, principally BGS seismic sub-bottom profiles, marine cores and Quaternary geological maps to examine substrate composition and aid landform interpretation. For convenience, we subdivide the following Results section into 3 distinct geographical/bathymetric 
areas: (i) The Minch and Hebrides Shelf; (ii) The Central sector; (iii) the West Shetland Shelf and Orkney-Shetland Platform (Fig. 5).

3.1.1 The Minch and Hebrides Shelf. Along the continental shelf edge in present-day water depths of $\sim 180-200 \mathrm{~m}$ and adjacent to the Sula Sgeir Fan the bathymetry data shows a single, continuous, broad ridge gently arcuate to the $\mathrm{SE}, 3-5 \mathrm{~km}$ wide, $20-30 \mathrm{~m}$ high and up to $60 \mathrm{~km}$ long. This is the largest, outermost MacDonald Formation moraine mapped at the shelfbreak and previously described by Stoker (1990) and Stoker and Holmes (1991) (see 1.2 above). Three morphologically similar, $10-15 \mathrm{~km}$ long, $2-5 \mathrm{~km}$ broad, arcuate ridges, are clearly visible $10-30 \mathrm{~km}$ to the $E$ (inboard) of the outermost moraine. These ridges are mapped from bathymetry data in the same location as fragmentary seabed moraines were recorded on seismic profiles by Stoker et al. (1993; Fig 77). As such, we interpret these outer shelf ridges collectively as broad subaqueous moraines (or grounding-line features) part of the Middle-Upper Pleistocene MacDonald Formation, with clear lateral extensions to the NE (Figs. 4-6) (see below, 3.1.2).

North of Lewis on the mid shelf in water depths of 100-120 m, are two large broad ridges trending across the wide cross-shelf trough linking the Minch to the Sula Sgeir Fan. The outer ridge, which we call the North Lewis Ridge, ranges in width from 2-5 km and has a maximum height of $20 \mathrm{~m}$ above the surrounding sea floor. This discontinuous ridge is 40-50 km long; however, the singlebeam bathymetry data is sparse in the central part of the ridge system, which consequently remains undefined. The main ridge is curvilinear in form arcing round from a northerly orientation offshore northernmost Lewis to an NE-SW orientation in its northern part, i.e. concave in planform towards mainland Scotland. Bathymetric cross profiles show no preferred slope asymmetry (Fig. 5). Seismic profiles show this region of seafloor is characterised by a featureless, in places acoustically transparent unit, which correlates with a 20-m thick stiff foraminiferous clay proved in BGS borehole 77/08 (Fyfe et al., 1993). The inner broad ridge, which we here call the North Minch Ridge, is a well imaged feature in the singlebeam data trending generally NE-SW between the North Lewis and North Minch basins. This continuous ridge is $20-25 \mathrm{~km}$ long, $10-20 \mathrm{~m}$ high and 3-6 km wide, with linear and curvilinear sections in planform. Singlebeam echosounder data show that the North Minch Ridge is asymmetrical in cross profile in its central section with a steeper NW-facing (distal) slope and a single broad crestline (Fig. 4). Bedrock does not outcrop in the vicinity of this ridge (BGS, $1989,1994)$. BGS seismic profiles show a thick Quaternary succession in and around the North Lewis Basin and BGS borehole 77/08 on the flank of the North Minch Ridge recovered $>20 \mathrm{~m}$ of stiff pebbly clay with arctic microfauna indicating glaciomarine sedimentation (Fyfe et al., 1993). Approximately 
midway along the North Minch Ridge a large broad flat-topped approximately rectangular mound occurs to the south, with a width of $5 \mathrm{~km}$, length of $8 \mathrm{~km}$ and a general N-S elongation. BGS seismic data shows a considerable thickness of Quaternary sediment in this region $(>50 \mathrm{~m})$, however, the seismostratigraphic sequence is unclear with the Pleistocene deposits left undifferentiated (Fyfe et al., 1993). Currently, no multibeam data exists for the outer or mid shelf NW of Lewis (Fig. 2), however the eastern part of the North Lewis Ridge is captured by multibeam bathymetry data (Fig. 6). This high-resolution bathymetry reveals a broad ridge $2-3 \mathrm{~km}$ wide with a generally smooth surface texture and no overall slope asymmetry, similar in form to large subaqueous moraines seen on the outer shelf (Stoker \& Holmes, 1991) (Fig. 7). Of particular note is the irregular pitted and scoured surface of the ridge crest along a $5-\mathrm{km}$ long section (Fig. 7). In this relatively shallow shelf setting ( $<80 \mathrm{~m}$ present day water depth) these are interpreted as keel marks of large icebergs, probably indicating former proximity to a calving ice-sheet margin.

Near the Flannan Isles, in the extreme west of the study area, are two large seabed ridges. The first is a broad low-elevation $15 \mathrm{~km}$-long ridge trending NE-SW at around $100 \mathrm{~m}$ present-day water depth on the outer shelf (Figs 4,5 ). This ridge is $2-5 \mathrm{~km}$ wide and typically 10-15 m high. BGS seismic profiles show a thin acoustically chaotic wedge of sediment draped on irregular basement bedrock in this area (Stoker et al., 1993). The second feature is a broad low-elevation ridge starting $20 \mathrm{~km} \mathrm{NW}$ of Bernera, west Lewis, which we term the East Flannan Ridge. At its maximum, it is $4 \mathrm{~km}$ wide, $10 \mathrm{~m}$ high, and $25 \mathrm{~km}$ long and is weakly arcuate to the south where it is bounded by the Flannan Trough. This ridge may be partly bedrock controlled to the north, as seen in its irregular cross profile, and terminates to the west on the submerged bedrock platform surrounding the Flannan Isles (Fig. 4). BGS seismic profiles show a thin poorly resolved sediment unit draped on bedrock, and seabed sediment maps show a broad belt of sandy gravel coincident with the East Flannan Ridge.

In the eastern Minch, large, arcuate seabed ridges occur in nearshore waters in present-day water depths of up to $100 \mathrm{~m}$ (Figs. 5, 6). A number of these are clearly visible in the singlebeam dataset, the most notable being a large ridge $1-2 \mathrm{~km}$ wide, up to $35 \mathrm{~m}$ high, and nearly $20 \mathrm{~km}$ long that extends $\mathrm{N}$ from the Stoer Penisula and arcs through almost 90 degrees to trend NW in the vicinity of Loch Laxford (Fig. 5). This large prominent sharp-crested ridge, here termed the Eddrachillis Ridge, has a simple asymmetric profile with a gentler eastern (proximal) flank and a steeper (distal) western flank - typical of large end moraines or grounding-zone features in submarine settings (e.g. Dowdeswell et al., 2008a; O Cofaigh, 2012). Five similar but smaller sharp-crested ridges 5-15 m high and 250-500 m wide, occur 1-2 km inshore of the Eddrachillis Ridge, all with similar asymmetric profiles - characteristic of recessional push moraines charting ice retreat from NW to SE. 
1 A BGS seismic profile (sparker) across the Eddrachillis Ridge (Fig. 8) shows it is comprised of a single generally chaotic to acoustically transparent unit with very few internal structures unconformably deposited on underlying strata, typical of glacigenic (morainic) diamicton laid down at the margin of a grounded ice sheet. The five smaller inshore ridges are comprised of the same laterally continuous acoustic unit. In the southeast, this uppermost glacigenic unit directly overlies Precambrian bedrock; in the northwest it is deposited on an offshore-thickening stacked sequence of Late Pleistocene sediments interpreted elsewhere as subglacial and ice-proximal glaciomarine facies (Sheena Formation., Morag Formation.) (Fyfe et al., 1993) (Fig. 8). The innermost ridge in the sequence has a very similar seismic expression and morphology to recessional moraines found on the seabed in the Summer Isles region to the south (see below) (Stoker et al., 2009). The stratigraphic position of the unnamed uppermost glacigenic unit (comprising the Eddrachillis Ridge and adjacent inshore ridges) within the existing regional seismostratigrphic framework is currently not clear. However, its superposed stratigraphic position and well-preserved seabed morphology demonstrate a late-stage glacial event, younger than the Sheena Formation (Upper Weichselian) but older than the Lateglacial climate reversal (Greenland Interstadial/Stadial 1), and therefore probably within the time period 20-15 ka BP.

The Eddrachillis Ridge may represent a northern equivalent of a similarly prominent late-stage moraine system imaged at the mouth of Loch Ewe and around the Rubha Coigach headland (Stoker et al., 2009) (Figs 5, 6). The Loch Ewe-Greenstone Point moraine complex is $1-2 \mathrm{~km}$ wide, up to $30 \mathrm{~m}$ high and $>15 \mathrm{~km}$ long and forms a long broad arc open to the SE. Low-resolution echosounder data suggest a bathymetric connection between this moraine complex and the morphologically similar moraines around the Rubha Coigach headland $\sim 20 \mathrm{~km}$ to the NE, although multibeam data is lacking in this intervening area. Multibeam echsounder data acquired by BGS (in 2005) and new baythmetry data from the eastern Minch acquired by MCA (in 2011) show the detailed geomorphology of this substantial moraine complex, in present-day water depths of 30-100 m. The larger moraines indicate firmly grounded retreat, whilst the superimposed de Geer moraines (1-5 m high; <100 m wide) suggest lightly grounded retreat of a tidewater glacier margin close to flotation (Stoker et al., 2009; Stoker \& Bradwell, 2011)

Morphologically similar seabed ridges occurring to the $\mathrm{N}$ of the Eddrachillis Ridge are well imaged on singlebeam data (Fig. 5). They form a nested sequence of nearshore ridges, ca. 10-20 km to the west and NW of Loch Inchard, in present-day water depths of 40-65 m. They are referred to here as the NW Sutherland ridges (Fig. 5). These 5 or 6 ridges vary in size and shape but all trend in the same direction (NE-SW); most of the ridges are generally arcuate in planform, concave to the SE (Fig. 6). 
1 The outer ridges are broader and generally lower whilst the inner ridges are higher and better defined; the innermost ridge is the most pronounced being $<1000 \mathrm{~m}$ wide and rising $20 \mathrm{~m}$ from the seabed. Most of the ridges have no overall slope asymmetry in cross profile (Fig. 5). The inner ridges due west of the Sheigra headland when projected along trend would make landfall in the vicinity of Sandwood Bay; the outermost ridges would make landfall further north in the vicinity of Cape Wrath (Fig. 6). BGS seismic lines across this part of the eastern Minch show these sediment ridges to a have a similar acoustic character to the Eddrachillis Ridge - with a single acoustically chaotic unit unconformably overlying an irregular bedrock reflector, characteristic of diamicton-dominated end moraines. Unfortunately, this group of well-developed ice-sheet moraines is outside the area covered by existing multibeam data (Fig. 2), hence more detailed morphological information is currently lacking.

All the nearshore moraines in the eastern Minch described in this section are relatively large, well defined, morpho-stratigraphically equivalent features in similar water depths. We therefore suggest they were broadly coeval in formation and informally assign these moraines to the Late Pleistocene deglacial succession, stratigraphically older than the Assynt Glacigenic Formation (<16 ka BP) further inshore and stratigraphically younger than the Fiona Formation-Loch Broom Till Formation ( $20-25$ ka BP) (Stoker and Bradwell, 2011).

In the south of the study area, from the Gairloch and Coigach headlands inshore to the heads of the fjords (Loch Ewe, Loch Broom and Little Loch Broom) are numerous transverse seabed ridges in water depths typically from 30 to $100 \mathrm{~m}$ (Fig. 9). This part of the eastern Minch known as the Summer Isles region was surveyed with multibeam echosounder and sub-bottom acoustic profiling by BGS in 2005, and over 100 seabed cores were recovered in separate scientific cruises in 2006 and 2009. The results of these data acquisitions have been the focus of detailed geomorphological and geological studies (Stoker et al., 2006, 2009; Stoker \& Bradwell, 2011). Over 50 seabed ridges have been mapped in the area trending generally SSW-NNE and varying in length from 0.5 to $5 \mathrm{~km}$; ridge spacings typically range from 500 to $1000 \mathrm{~m}$. There are 2 distinct sets: an older group of more substantial ridges (5-15 $\mathrm{m}$ high; 80-150 $\mathrm{m}$ wide), and a younger group of smaller more delicate ridges (2-5 $\mathrm{m}$ high; 30-50 $\mathrm{m}$ wide), superimposed on the earlier ridges (Fig. 9). Most ridges are simple in planform consisting of linear sections; however some are more intricate in planform describing intricate or zigzag patterns. Occasionally ridges continue to water depths of $100 \mathrm{~m}$ but in basins and bathymetric deeps the ridges are notably absent. The larger ridges are typically asymmetric in cross-profile, whilst the smaller more delicate ridges tend to be symmetrical. BGS seismic profiles show the ridges to be typically composed of a single acoustically chaotic or 
structureless unit draped unconformably on an irregular bedrock surface (Fig. 9). A core taken from the flank of a seabed ridge recovered a massive, poorly sorted, sandy to muddy diamicton with numerous striated clasts of non-local lithology (Stoker et al., 2009). The whole suite of seabed ridges have been lithostratigraphically assigned to the Assynt Glacigenic Formation and are interpreted as subaqueous moraines (and/or de Geer moraines), formed at the grounded, or partially buoyant, tidewater margin of a retreating ice sheet (Stoker et al., 2006; Stoker et al., 2009). In places, around the mouths of Loch Broom and Little Loch Broom these moraines have clear onshore counterparts which have been studied and in places dated with terrestrial cosmogenic nuclides ( 15 ka BP; Bradwell et al., 2008b).

3.1.2 Central Sector. The seabed in the central sector of the study area is generally shallower, more rugged and more topographically variable than the shelf areas to the SE and NW. The bathymetry is punctuated by a number of large structural bedrock highs and platforms on the mid shelf; these include the North Rona, Solan Bank, and Nun Rock-Sule Skerry Highs (Figs 1). Extensive singlebeam data coverage and good multibeam data coverage exists for this part of the shelf affording an excellent view of the seabed geomorphology (Fig. 5). The seabed in this central sector is characterised by an abundance of seabed ridges, with over 100 mapped in this study.

Approximately 5-30 km from the shelf break, on the outer shelf, 30-50 km NE of North Rona at least four large, broad ridges extend semi-continuously for $\sim 100 \mathrm{~km}$ in a NE-SW direction parallel to the continental shelfbreak. They are typically between 3-4 km wide increasing in width (to 4-5 km) to the NE with smooth subdued cross profiles (Fig. 5). The ridges are generally low-elevation features ranging in height from 10-20 m. Overall the ridges are broadly arcuate in planform but with long linear sections (Fig. 6). The exact plan morphology of the ridges is not easy to establish, even with image enhancement, owing to their subdued form and the vertical resolution of the singlebeam data. However, the new mapping is an improvement on that presented in Bradwell et al (2008a) and gives a better impression of the lateral continuity and spatial inter-relationship of these ridges; for example it is clear that the outermost fragmentary ridge is cut out or overprinted, at least in part, by the adjacent inshore ridge (Fig. 6). BGS seismic profiles across this part of the outer shelf show acoustically structureless or chaotic packages in the upper part of the sequence ( $<40 \mathrm{~m}$ thick) which occasionally interdigitate with layered deposits near the shelf break. BGS seismostratigraphic mapping supported by borehole evidence places these NE-SW trending broad ridges within the Murray or MacDonald Formations (Stoker et al. 1993; BGS, 1994) - a Late Pleistocene suite of iceproximal to glaciomarine sediments laid down prior to the Otter Bank Formation (Stoker and 
Holmes, 1991). Whereas, spatial relationships revealed in the new bathymetry data (this study) suggest that the inner three ridges can be traced onto the northernmost part of the Hebrides Shelf seemingly offering a potential correlation with the MacDonald Formation moraines at seabed - their stratigraphic relationship (angular discordance) with other Pleistocene deposits must be taken into consideration in any proposed reconstruction (Fig. 4).

Further inshore, on the mid shelf to the NE of North Rona, another group of seabed ridges are well imaged on the singlebeam bathymetry. For convenience, we term these collectively the $\mathrm{N}$ Rona Ridges (Fig. 5). Four large broad ridges interspersed with several smaller ridges occur in present day water depths of 80-130 m, in a region of highly variable bathymetry including the North Rona Basin and western part of the Solan Bank High (Figs 5, 6). The larger ridges are 2-4 km wide and 10-20 m high; the smaller ridges are up to $2 \mathrm{~km}$ wide and of similar vertical relief (10-20 m). The North Rona ridges arc round from a NE-SW trend to an E-W trend in their eastern parts and extend for $\sim 50 \mathrm{~km}$ on the mid shelf where they abut a larger feature (the Solan Bank Ridge) on the mid shelf. The inner suite of ridges appear to fan out from the North Rona High, suggestive of topographic pinning; whereas the outer suite of ridges are more shelf-edge parallel features (Fig. 6). Most of the ridges comprise discontinuous sections with the longest continuous ridge extending for ca. $30 \mathrm{~km}$. The spacing between successive ridges is relatively close near the North Rona high, with six main seabed ridges mapped in only $15 \mathrm{~km}$ of horizontal distance (Figs 5,6 ).

Multibeam bathymetry covers only a small part of this area to the east of North Rona (Fig. 2), Here the 3-D shape and smooth surface of the North Rona sediment ridges can be clearly seen as well as their unconformable relationship with the underlying basement bedrock. These ridges have strong morphological similarities with subaqueous moraines mapped elsewhere in the study area (e.g. in the eastern Minch) and in other glaciated continental shelf settings (e.g. Shaw et al., 2006; Todd et al., 2007; Dowdeswell et al., 2008). Unfortunately, this whole region is not well resolved in BGS seismic lines as bedrock is near to seabed across much of the area and correlation of thin discontinuous Pleistocene sequences is difficult (Fig. 3). However, BGS Quaternary geology maps and offshore reports assign the Pleistocene deposits in this region to the Otter Bank Formation: a heterogeneous glaciogenic unit comprising ice-proximal diamictons, glaciofluvial/deltaic gravelly sands, and glaciomarine pebbly muds (Stoker et al., 1993; BGS, 1994). Interestingly, the narrower innermost east-west trending North Rona moraine ridge seems to join, or be truncated by, a broader NNE-SSW trending sediment ridge in shallow water projecting from the northern edge of the Solan Bank High, but the exact morphological relationship remains unclear (Fig. 6). 
1 A prominent NNE-SSW trending bathymetric high crosses the mid shelf between the submerged bedrock high of the Solan Bank (60 m water depth) and the main Otter Bank Formation Moraines (100-120 m water depth). This prominent $10-20 \mathrm{~km}$ wide, $80 \mathrm{~km}$ long feature is a structural bedrock platform - referred to as the Solan Bank High. BGS investigations proved basement rocks of the Lewisian complex at seabed on the Solan Bank and the adjacent Sule Skerry-Nun Rock high (Ritchie et al., 2011). BGS borehole 77/07 recovered weathered basement rocks at shallow depth beneath Tertiary and Neogene deposits on the spine of the Solan Bank High (Stoker et al., 1993). Although predominantly a bedrock feature, seismic records show that the eastern portion of the platform is capped by a thin Pleistocene sequence (Otter Bank Formation) which thickens to the northeast (Stoker et al., 1993). We map a low broad NNE-SSW-trending sediment ridge along the length of the eastern side of the Solan Bank High which we call the Solan Bank Ridge. It is 3-4 km wide and generally rises only 10-15 m above the surrounding seafloor with low angle slopes and a very poorly defined crestline (Fig. 6). However, its geometry is consistent with other subtle ice sheet moraines seen on the mid and outer shelf. A morphologically similar broad, low ridge occurs on the northern part of the Solan Bank High where the glacigenic Otter Bank Formation thickens forming more pronounced moraines (morainal banks) (Stoker et al., 1993).

Inshore of the Solan Bank High, the number and density of seabed ridges increase considerably (Fig. 10). This area of rugged seafloor punctuated by numerous bedrock highs is well imaged in both the singlebeam and multibeam data. The density of seabed ridges is typified in the area S of Solan Bank around Nun Rock -a rugged basement high that reaches to within -30 m of present day sea level (Figs. 1, 4). Detailed mapping of ridges in this region reveals numerous sediment ridges with complex planform morphology and variable 3D shape (Figs. 10, 11). The ridges on this part of the shelf have notably more variable geomorphology than the broad simple planform ridges seen on the outer and mid shelf (Figs. 5, 6). Some show clear overprinting or superimposed relationships (Fig. 10). The seabed ridges inshore of the Solan Bank High and around Nun Rock generally fall into 2 types: broader, more substantial, ridges with widths ca. 200-1000 m and heights of 5-10 m; and narrow, more delicate, ridges with widths ca. $100 \mathrm{~m}$ and heights of only 1-3 m above the surrounding seafloor. The larger ridges have variable geomorphology, often with strongly arcuate sections and numerous inflection points (Fig. 11). Ridge crests are generally broad and rounded; along-ridge heights can vary; most are slightly asymmetric in cross-profile steeper on their shoreward (proximal) side. They are also nearly always continuous features, with very few breaks or missing sections. By contrast the smaller ridges tend to be simple in planform with linear or curvilinear sections and rarely extend more than $2-3 \mathrm{~km}$ without a break. Ridge crests are sharper and better defined; however slope asymmetry is often lacking. 
Immediately south of Nun Rock is an excellent example of one of the large continuous ridges found in the central part of the shelf off northern Scotland (Fig. 11). The ridge starts in the shallow water adjacent to Nun Rock and ends on the bedrock platform around Cape Wrath, traversing water depths from $-55 \mathrm{~m}$ to $-95 \mathrm{~m}$ below present day sea level. Running almost due N-S and unbroken for $22 \mathrm{~km}$, we term this the Nun Rock Ridge. The ridge ranges in width from $\sim 250$ to $\sim 1000 \mathrm{~m}$ and averages around 8-10 $\mathrm{m}$ in height. Bathymetric cross-profiles show that asymmetry is typical with slope gradients of between 50:1 to 80:1 and a generally steeper east-facing slope (Fig. 11). The continuous, well-defined morphology of this feature on the seabed is striking. In particular, the arcuate, almost semi-circular, ridge sections concave to the E-SE; the numerous strong kinks or inflections where the ridge direction changes by up to 90 degrees; and the irregular, multi-lobed, overall planform of the ridge (Fig. 11).

The BGS seismostratigraphic framework is poorly developed in the nearshore region around NW Scotland with most deposits defined simply as "Quaternary undifferentiated" (Fig. 4). This is largely owing to the thin $(<5-10 \mathrm{~m})$ and patchy nature of the Pleistocene deposits on bathymetrically rough seabed (BGS, 1989; Stoker et al., 1993). The Nun Rock Ridge is only poorly resolved on one or two BGS seismic profiles (airgun and sparker), owing to its small size, but is composed of a structureless acoustically transparent unit unconformably overlying highly reflective substrata interpreted as hard (?crystalline) bedrock (Fig. 11). BGS borehole 72/34, situated on the flank of the ridge, proved $8.5 \mathrm{~m}$ of grey silty, sandy, clay with ice-worn pebbles and occasional sand lenses typical of a glacial diamicton, overlying bedrock (Stoker et al., 1993). Maps made from seabed sediment samples show gravelly sands and gravels predominating on the highs (ridges) whereas sands predominate in the basins (BGS, 1989). Taken collectively the morphological and geological evidence, combined with the similarity to well-studied glacial features identified elsewhere on the seabed around NW Scotland (e.g. Stoker et al., 2006, 2009), strongly favours the interpretation of the Nun Rock Ridge as a prominent end moraine, relating to a stillstand or oscillation of a grounded ice sheet margin.

Immediately adjacent to this seabed moraine, 1-2 km E, another less continuous but comparably sized ridge mirrors its planform shape with curves and inflection points in similar places along much of its length (Fig. 11). Approximately $10 \mathrm{~km} \mathrm{E}$ of this a further prominent seabed ridge occurs with similar dimensions and characteristic curved-and-kinked morphology. Like the Nun Rock Moraine, this broad-crested ridge is also asymmetric in cross-profile with east- and west-facing slope gradients of $80: 1$ and 100:1 (Fig. 11). Based on their geomorphological similarity and spatial coherence with the Nun Rock Moraine, we also interpret these substantial ridges as end moraines, part of a suite of 
1 'regional moraines' imaged in multibeam bathymetry data charting the retreat of a grounded ice sheet margin offshore northern mainland Scotland (Figs 6, 11).

The smaller, more delicate, ridges seen immediately $W$ of the Nun Rock Moraine, form a different suite of 4 (or possibly 5) ridges on the seabed. With wide spacings of 500-1000 m and heights of only 1-3 $\mathrm{m}$, these ridges bear little similarity to marine (sediment transport) bedforms; their contextual setting adjacent to, and between, ice sheet moraines suggest a Pleistocene age and origin. Although geological and acoustic information about their composition is lacking, their morphological similarity to small subaqueous transverse moraines (de Geer moraines), identified elsewhere in formerly glaciated continental shelf settings, is strong (e.g. Ottesen \& Dowdeswell, 2006; Todd et al., 2007; Bradwell et al., 2008b). On this basis we map these suites of smaller ridges in the vicinity of Nun Rock as de Geer-type moraines formed by incremental retreat of an ice-sheet grounding line over time (e.g. Linden \& Moller, 2005). The stratigraphic and temporal relationship between these smaller moraines and the more substantial regional moraines is not clear, although there is a suggestion in the multibeam data that the former overprint or truncate the latter in places. It is very likely, judging by their good state of preservation, that all these moraines relate to the last (Late Weichselian) BIIS.

Multibeam echosounder data also reveals an irregular hummocky area of seabed geomorphology with faint linear N-S orientated forms between the two large regional moraines (Fig. 11; RM1 and RM2). Sub-bottom geophysical profiles show thin and patchy Pleistocene sediment cover with bedrock at or close to seabed (Fig. 11); geological maps (BGS, 1989, 1984) show undifferentiated Quaternary deposits in this area with gravelly seabed sediments predominating. It is likely that some of the hummocks and discontinuous linear forms in the multibeam data may be glacigenic (morainic) in origin. It is notable that a further 3 small, delicate, morphologically distinct, but discontinuous ridges are seen with the same N-S orientation on the eastern margin of this hummocky area near RM2. We interpret these small discontinuous ridges as de Geer moraines, part of the Nun Rock moraines suite (described above).

The suite of regional moraines imaged between Cape Wrath and Nun Rock continue eastward at a high angle to, in places almost perpendicular to, the present-day north coast of Sutherland (Fig. 6). A notable deviation from this trend is offshore Faraidh Head, $\mathrm{N}$ of the mouth of Loch Eriboll in water depths of 50-70 m, where large, morphologically similar, but more pronounced, transverse ridges are seen to interrupt or overprint this regional pattern (Fig. 12). Interpreted as a subsequent suite of ice-marginal landforms, the Faraidh Head moraines form a group of up to 10 discrete arcuate, but 
laterally discontinuous, nested ridges. Their geomorphological and acoustic similarity with the Nun Rock moraines, as well as their discontinuous concentric pattern, is strongly suggestive of a grounded or partly grounded ice margin retreating from $\mathrm{N}$ to $\mathrm{S}$ - evidence of a locally sourced ice mass in the mountains of NW Scotland (Fig. 12). The superimposition of one set of moraines on another in this area suggests that a major local ice sheet/ice cap readvance occurred in NW Sutherland, and furthermore that final retreat of this ice mass probably occurred under marine conditions hence the preservation of both sets of landforms.

Further east in the central sector the singlebeam bathymetry data shows the suite of regional moraines continuing adjacent to the north coast of Sutherland and Caithness (Fig. 6). The spatial pattern of the ridges continues, with lobate or broadly arcuate planforms open to the E or SE. Bathymetric cross profiles also show similar height and widths to the moraines in the vicinity of Nun Rock and generally steeper east-facing slopes. In several places, between Faraidh Head and Dunnet Head, these large moraines are truncated or overprinted by another set of equally substantial seabed ridges; implying a subsequent phase of glacial advance-retreat. One notable ridge complex highlights this relationship. A broad seabed sediment ridge can be seen extending offshore in an ENE direction to the east of Strathy Point (Fig. 6). If projected onshore this ridge would make landfall in the vicinity of Melvich Bay; hence we call this the Melvich Ridge. Approximately $15 \mathrm{~km} \mathrm{~N}$ of Sandside (Reay) Bay, this broad subdued ridge is overprinted by another smaller, but more prominent seabed ridge with a well-developed crestline (Fig. 13). This sharp-crested ridge forms a wide arc stretching over $40 \mathrm{~km}$ from the Caithness coast, between Reay and Brims Ness, to $10 \mathrm{~km} \mathrm{~W}$ of Hoy in Orkney. Good quality singlebeam bathymetry data shows that this ridge is 400 to $1000 \mathrm{~m}$ wide and typically 10-20 m high with an unusual asymmetry, being generally steeper on its westfacing slopes. In places, the ridge crestline widens, bifurcates or splits into two well-defined ridges, with one ridge set $\sim 1 \mathrm{~km}$ inside the other (Fig. 13). At a point c. $10 \mathrm{~km} \mathrm{~W}$ of Rora Head on Hoy the ridge sharply changes direction, and continues with the same distinctive sharp-crested morphology in a northerly direction in present day water depths of 60-80 m. Unfortunately, this ridge is not well imaged in existing seismic sub-bottom survey lines, although an airgun profile clearly shows the twin-crested morphology of the ridge, its relatively high-angle slopes and asymmetry (steeper westfacing slopes) (Fig. 13). As elsewhere on the inner continental shelf, the 3-d morphology (e.g. height, width, shape etc.) and geospatial similarity (e.g. spacing and trend) of the ridges between Faraidh Head and Dunnet Head to other seabed moraines imaged elsewhere on the UK continental shelf strongly suggest that they formed at the margin of a grounded ice sheet, probably during the Late Weichselian period. We suggest that the superimposed Reay Ridge represents a notable and 
spatially extensive moraine-forming event during overall ice-sheet retreat, when the ice sheet margin underwent a significant readvance, in places beyond the position of older moraines (Fig. 13).

3-8 km east of the Reay Ridge are numerous closely spaced, prominent, sharp-crested seabed ridges trending generally N-S, but with irregular spacings and occasionally branching planform (Fig. 13). The ridges are 10-20 m high and up to $1000 \mathrm{~m}$ wide; some are symmetrical in cross profile whilst others have strong asymmetry (both east-and west-facing) with asymptotic slopes. They are currently only imaged in singlebeam, not multibeam, data. Their setting at the western entrance to the Pentland Firth in a hydrographic region renowned for its strong tidal currents (Kenyon \& Stride, 1970) suggest that they are probably large-scale, mobile (but long-lived), sediment transport features (i.e. sand waves). Similar features have been mapped as sand waves on the seabed between Orkney and the Scottish mainland (Stoker et al., 1993). Seismic (airgun and sparker) profiles across this field of ridges are equivocal, showing prismatic structureless sediment bodies unconformably overlying acoustically bedded hard substrate (probably bedrock) (Fig. 13). However, the possibility that the ridges are reworked, glacigenic features (end/de Geer moraines) or have a glacial sediment core, cannot be ruled out at this time.

\subsubsection{West Shetland Shelf and Orkney-Shetland Platform. Considerable previous work has} been done on characterising the seabed morphology, seismic architecture and Quaternary geology of the West Shetland Shelf. The following section draws on this literature whilst summarising the range of glacial landforms seen in the bathymetry data on the continental shelf around Orkney and west of Shetland.

Adjacent to the shelfbreak in water depths of $160-200 \mathrm{~m}$ are a suite of ridges; two large broad ridges and two smaller intervening ridges (Figs 5,6 ). The longest of these extends semi-continuously for $>120 \mathrm{~km}$, beyond the northern limit of the study area, in a NE-SW direction parallel to the continental shelf edge. The broad ridges are the largest depositional features imaged on the continental shelf, being typically between 3-5 km wide and ca. 20-30 m high; the two intervening ridges are only 1-2 km wide (Fig. 6). All the ridges have smooth low-aspect cross profiles with very broad almost imperceptible crests. NW-facing (distal) slopes tend to be slightly steeper than SEfacing (proximal) slopes, though the exact plan morphology of the ridges is not easy to establish, even with image enhancement, owing to their subdued form. The ridges are part of a wider suite of glacigenic deposits on the West Shetland Shelf identified in seismic data by Stoker \& Holmes (1991) and interpreted as ice-sheet end moraines. This whole suite of shelf-edge and mid-shelf moraines 
1 form part of the Upper Pleistocene (Late Weichselian) Otter Bank Formation, as defined by Stoker et

2 al. $(1993,2011 a)$. Further work on their acoustic character and internal architecture has been carried out by Davison (2005).

4 New mapping of these moraine ridges from echosounder imagery (Fig. 6) shows their spatial 5 relationships more clearly; with the inner broad ridge abutting, and partially overprinting, the outer 6 ridge along the northernmost part of the shelf in the study area. The moraines appear to stop 7 abruptly where the shelf edge (200 m water-depth contour) makes a re-entrant inshore - known as the Foula Bight (Fig. 1, 6). BGS seismic profiles across this part of the outer shelf show relatively thin ( $<20 \mathrm{~m}$ thick) acoustically structureless or chaotic packages within the broad ridges (Otter Bank Formation) passing laterally into layered deposits, part of the Morrison Formation on the West Shetland Slope (Stoker et al., 1993; Stoker 1995; Davison, 2005).

Approximately $20 \mathrm{~km}$ to the SW, on the mid shelf, are another suite of large broad ridges, $(\sim 2-5 \mathrm{kms}$ wide; 20-50 m high) with concentric, arcuate or lobate morphology, some with zigzag or convoluted plan forms. The whole suite has been interpreted as a complex of Late Weichselian ice-sheet end moraines; the outermost ridges forming part of the Otter Bank Formation, the innermost forming part of the Stormy Bank Formation (Stoker et al., 1993). The geomorphology and seismic architecture of this sequence has been described previously in detail by Stoker \& Holmes (1991), Stoker et al., (1993) and Bradwell et al. (2008a). These seabed landforms are clear in the singlebeam bathymetry and represent the densest clustering of large moraines on the continental shelf within the study area (Figs 5, 6). Our mapping merely refines earlier work showing that there are 9 or 10 large nested ridges within $50 \mathrm{~km}$ horizontal distance; some of them showing clear overprinting relationships.

Correlation of the outermost Otter Bank Formation moraines in this group with the large moraines west of Shetland (Stoker \& Holmes, 1991; Stoker et al., 1993) is possible based on seismostratigraphical and geomorphological grounds. However, correlation of the inner moraines in this group (Stormy Bank Formation) with ridge fragments on the West Shetland Shelf to the north remains equivocal, as a large area of bedrock occurs at seabed in this area $\sim 60^{\circ} \mathrm{N}$ (Fig. 6).

To the SE of the relatively shallow Otter Bank moraines (80-120 m water depth) the seabed deepens inshore, reaching $-180 \mathrm{~m}$ in the parts of the broad Westray Basin, before rising abruptly at the Orkney-Shetland Platform (Fig. 14). A conspicuous well-defined ridge with a distinctive lobate or looped pla form occurs in water depths of ca. $110-130 \mathrm{~m}$ on this adverse-sloping seabed, $\sim 10 \mathrm{~km}$ to the SE of the main Otter Bank-Stormy Bank moraine complex, described above. This ridge forms the 
innermost (youngest) large regional moraine within the Otter Bank-Stormy Bank sequence; we call it the Westray Loop Moraine (Fig. 14). This sharp-crested ridge forms a 70-km long loop with a remarkable degree of morphological continuity. Good quality singlebeam and multibeam bathymetry data shows that this ridge is 400 to $1600 \mathrm{~m}$ wide and typically $10-20 \mathrm{~m}$ high with strong asymmetry, being notably steeper on its east-facing (proximal) slopes. In places, the ridge crestline widens or splits into two well-defined ridges. Occasionally these ridge bifurcations enclose small intra-ridge basins; one such notable basin is $\sim 1 \mathrm{~km}^{2}$ in area (Fig. 14). In other places another small fragmentary ridge is set back $1-3 \mathrm{~km}$ inside the main ridge complex. The ridge has been previously interpreted by Bradwell et al. (2008a) as a lobate ice-sheet end moraine, possibly formed during a dynamic (?rapid) oscillation of the ice margin. BGS seismic data across the double-crested moraine would tend to support this interpretation with strong parallel sub-surface reflectors within the ridge complex being truncated by a low-angle disruption plane at depth, interpreted here as a thrust (Fig. 14). Similar tectonic structures are often seen within contemporary thrust-block moraines, commonly associated with surging behaviour (Evans and Rea, 2003). Inboard of the Westray Loop Moraine, seismic reflection data show that the main part of the Westray Basin is covered in a relatively thick (>20 m), acoustically layered, fill of glacial (?glaciomarine) and postglacial sediments overlying a strongly undulating, probably glacially moulded, erosion surface (Fig. 14).

A large proportion of the seabed on the inner shelf around Orkney and Shetland consists of exposed bedrock, with structurally juxtaposed Lewisian, Moine, Devonian and Permo-Triassic rocks (Stoker et al., 1993; Ritchie et al., 2011). This exposed bedrock is clearly imaged and can be mapped from the echosounder bathymetry imagery, with a rugged highly irregular surface in multibeam data and a noisy chaotic seabed texture in singlebeam data (Fig. 14). Across this predominantly bedrock seabed, numerous small sediment ridges are seen particularly around northern Orkney and in the OrkneyShetland Channel. These ridges generally occur in shallower water depths $(<120 \mathrm{~m}$ below present day sea level) and are well developed, continuous, linear features. Excellent examples are seen 5-20 km west of Westray on the gently sloping western flank of the Orkney-Shetland platform. Here a suite of eight transverse ridges trend broadly NNE-SSW, in water depths of -120 to $-60 \mathrm{~m}$, with linear, curvilinear or gently arcuate plan forms (Fig. 15). Most ridges can be traced semi-continuously for 20$30 \mathrm{~km}$, although shorter ridge fragments <3-10 km in length also occur. Ridges are typically $100-300 \mathrm{~m}$ wide and 1 to $5 \mathrm{~m}$ in height. Ridge spacings are fairly regular and in the range 1000 to $3000 \mathrm{~m}$. Most ridges have simple crestlines, but one or two ridges bifurcate or display multiple crestlines. In crossprofile, ridge asymmetry is quite marked with almost $60 \%$ of moraine profiles ( $n=40$ ) showing a steeper east-facing slope, although reversed asymmetry is noted locally (Fig. 15). Although no seismic sub-bottom profiles across these features were examined, the ridges are clearly draped directly on 
bedrock, corroborated by BGS seabed sediment maps, with little or no other Pleistocene deposits in the vicinity. The distinct morphological similarity of these transverse ridges with subaqueous moraines elsewhere strongly suggest that they are recessional moraines, probably de Geer moraines, deposited by a grounded ice front terminating in water (e.g. Linden \& Moller, 2005; Ottesen \& Dowdeswell, 2006). Large, isolated sandbanks, presumed to be Holocene, with distinctive slope morphology and EW orientation are also seen in the shallows ( $<50 \mathrm{~m}$ water depth) close to the coast of Westray (Fig. 16).

Other equivalent transverse seabed ridges, with similar dimensions and ridge spacings occur in the waters around the Orkney Islands, particularly in North Sound between Westray and Sanday in present-day water depths of 20 to $70 \mathrm{~m}$ (Fig. 16). Collectively we assign a common glacigenic (morainic) origin to these suites of transverse ridges with similar 3-d morphology and dimensions. Although the slope asymmetry may vary (steeper distal- vs proximal slope) as well as the absolute dimensions, the de Geer-type moraines mapped on the Orkney-Shetland platform are easily distinguished in multibeam bathymetry from more recently formed sandbanks, sand waves, or linear bedrock structures (Fig. 16). Owing to the very thin and patchy distribution of Pleistocene deposits on this part of the inner shelf, the Quaternary sequence around northern Orkney is undivided. However, on the basis of the regional stratigraphic overview (Stoker et al., 1993) any glacigenic sediments in this region are expected to fall within the Stormy Bank Formation (Stoker et al., 2011a, b). The steepsided, fresh-looking form and good state of preservation of the Westray and North Sound moraines is entirely consistent with a Late Weichselian age, though no absolute age constraints currently exist (Figs. 15, 16).

Around 30 to $50 \mathrm{~km}$ to the east of the Pentland Firth, in relatively shallow water $(60-80 \mathrm{~m}$ water depth) to the SE of Orkney, are a number of seabed ridges and banks of differing scale and morphology clearly imaged in both singlebeam and multibeam data (Figs. 5, 6, 17). The three largest (and oldest) features are a collection of NE-SW trending low, broad, discontinous ridges and mounds. The main ridge belts are 1-4 km wide and elevated only 5-10 $\mathrm{m}$ above the surrounding seabed with gentle slopes and wide subtle, sometime multiple, crestlines (Fig. 6). These features continue to the NE, outside the area covered by this study. Quaternary deposits in the area to the east of Orkney and the outer Moray Firth are not well understood owing to the thin and patchy nature of Pleistocene deposits; those that are defined in BGS maps and reports are left undifferentiated (BGS, 2013). Furthermore, no formal correlation has yet been made between glacial sediment sequences and landforms to the E of Orkney with those to the W of Orkney (e.g. Otter Bank Formation, Stormy Bank Formation, etc) (Stoker et al., 1993; Andrews et al., 1990). 
1 Superimposed, in places, on top of these broad ridges is a second set of more delicate NE-SW trending transverse seabed ridges. These form suites of narrow closely spaced curvilinear ridges with well-defined, sometimes bifurcating, crestlines. In one suite, approximately $40 \mathrm{~km} \mathrm{E}$ of Duncansby Head, 15 well-developed but discontinuous ridges are seen in a horizontal distance of $\sim 10 \mathrm{~km}$ at the extreme eastern edge of the study area (Fig. 17). The longest ridges can be traced laterally for $\sim 20$ $\mathrm{km}$, although most are shorter and continuous over only 5-10 km or less. Most ridges occur within a well-defined elevation threshold between 65 and $75 \mathrm{~m}$ below present day sea level; several ridges terminate abruptly where the seabed deepens (>75 m water depth). Ridges are typically 100-200 m wide and 1 to $5 \mathrm{~m}$ high; ridge spacings are in the range $\sim 300$ to $1000 \mathrm{~m}$. In cross-profile, ridge asymmetry is marked with most ridges possessing a steeper W or NW-facing slope, although symmetrical and reversed asymmetry is noted in one or two cases (Fig. 17). No high-resolution seismic lines were available for this area hence the internal sediment architecture could not be examined. However, the co-spatial presence of (presumably Holocene) marine bedforms in the multibeam data, with markedly different morphologies and orientations to both generations of seabed ridges, suggest that the ridges are not related to present-day marine bedforming processes (Fig. 17). This fact and the strong morphological similarity of the smaller transverse ridges to subaqueous moraines elsewhere strongly suggest that they are Pleistocene glacigenic landforms, probably de Geer moraines akin to those seen elsewhere around Orkney (cf. Figs, 15, 16). The collective evidence suggests that they were deposited by a large ice mass terminating in shallow water and retreating in a north-westerly direction back towards Orkney. The larger more subdued ridges are probably older (?terrestrial) end moraine complexes deposited during an earlier stage of firmly grounded ice sheet retreat and subsequently overprinted by De Geer moraines with a similar orientation recording retreat of a lightly grounded (partly floating) tidewater ice-sheet margin.

\section{Discussion}

\subsection{Ice sheet reconstructions from submarine glacial landforms}

Previous work has shown the general pattern of ice-sheet moraines around Northern Scotland, based solely on low-resolution echosounder bathymetry from the continental shelf (Bradwell et al., 2008a). The wider pattern of ice sheet retreat across the British Isles was subsequently proposed by synthesizing all the available onshore and offshore geomorphological data (Clark et al., 2012). We use the pattern of ice-marginal landforms, mapped here from singlebeam and new multibeam echosounder data (Fig. 6) and supported by seismiostratigraphic interpretations and published 
1 Quaternary geological information, to reconstruct in more detail the ice-sheet configuration around northern Scotland at maximal extent and during deglaciation. Palaeo-ice margins are reconstructed based on the position and orientation of ice-marginal landforms (i.e. moraines and grounding-zone features) as done routinely in numerous palaeo-glaciological studies onshore and offshore (e.g. Bennett and Boulton, 1993; Benn et al., 2003; O Cofaigh et al., 2012; Rydningen et al., 2013). However, it is especially important that the stratigraphic relationships established between the different moraine-bearing formations are fully considered when attempting to reconfigure the palaeo-ice margins. Digitised crest lines, based on digital surface model data, or high points (where no crest could be discerned) of mapped moraines were used to mark the position of the former ice front. Adjacent, along strike, crest lines were then joined using a continuous line where they form obvious chains, or coherent sequences; dashed lines were used where the interpretation is less certain. For example, dashed lines show a sense of connectivity between seabed moraines where extensive areas of bedrock are present at seabed or bathymetric data is lacking. Careful consideration of the bathymetry/topography was made at all times to improve the glaciological plausibility of reconstructed ice margins, especially when interpolating ice-margins over long distances $>20 \mathrm{~km}$. In certain areas, where glacial landform evidence is absent or very complex and difficult to interpret, no correlations with adjacent landforms were made. It should be remembered that the resulting map of reconstructed palaeo-ice margins is only firmly constrained where data coverage and landform evidence is good (see Figs. 2, 5). Interpolated ice margins are clearly open to interpretation and we accept that other glaciologically plausible scenarios may exist. Furthermore, these reconstructions are likely to be refined and clarified in places, given the large amount of multibeam data becoming available from UK waters every year. Finally, no correlation with onshore moraines has been attempted in this work, owing to time constraints and the variable quality and vintage of Quaternary geological mapping in northern mainland Scotland and the Outer Hebrides (Clark et al., 2004; Evans et al., 2005; BGS, 2012). However, it is hoped that improved onshoreoffshore correlations will form the focus of future research.

\subsection{Ice sheet retreat pattern and evolution}

Our map of reconstructed ice margin positions around northern Scotland clearly shows the variations in ice sheet extent and geometry over time (Fig. 18). The overall pattern represents a large sector of the BIIS undergoing a widespread, but punctutated, size reduction - accompanied by significant changes in geometry - as it retreats, reorganizes and ultimately disappears, in response to internal and external drivers. These general findings echo those put forward by Bradwell et al. (2008a), based solely on singlebeam bathymetry data; but our detailed findings in the NW sector 
differ from the general 3-stage model we proposed in 2008 as well as some of the 'timeslice' reconstructions of Clark et al. (2012).

Examining the geographical distribution of ice-marginal landforms more closely, a detailed pattern of ice-sheet retreat emerges. Importantly, when combined with the distribution of Quaternary (Pleistocene) deposits on the NW UK continental shelf, compiled independently from seismostratigraphical evidence in the 1980s (Stoker et al., 1993), the pattern becomes more coherent and is firmly supported within a lithostratigraphic (relative-chronological) framework (Fig. 18). The overall pattern depicted in Figure 18 is subdivided into 10 key stages outlined below:

- Stage 1 - Large shelf-edge moraines adjacent to the Sula Sgeir Fan (MacDonald Formation moraines) indicate that grounded ice sheets extended across the Hebrides Shelf during the Mid to Late Pleistocene $(<0.45 \mathrm{Ma}$ ), but probably did not reach this far during the Late Weichselian (MIS 2) (Stoker et al., 1993; Stoker, 2013). Morphologically similar shelf-edge moraines occur on the outermost parts of the shelf in the Central sector and West of Shetland (Murray and Otter Bank Formation moraines); however, the mapped stratigraphic relationships between all three major units indicate that they are probably not directly timeequivalent (Figs. 3, 4). The combined morphological and seismostratigraphic evidence suggests that at Stage 1 an extensive ice sheet fed the substantial continental-slope Sula Sgeir Fan, via the Minch ice stream, depositing glacigenic debris flows and glaciomarine muds (within the Macauley Fm., Upper Macleod Fm. and Morrison Fm) (e.g. Stoker et al., 1993; Stoker and Bradwell, 2005; Bradwell et al., 2007). This ice-sheet front probably also extended as a marine-terminating margin at, or close, to the shelf edge from west of Lewis $\left(\sim 58^{\circ} \mathrm{N}\right)$ to west of Shetland $\left(>61^{\circ} \mathrm{N}\right)$ prior to MIS 2-3. Parts of the ice front may have extended into deeper water as floating ice shelves especially where the indented bathymetry of the shelfbreak potentially allowed the ice sheet to be laterally supported (e.g. Wyville-Thomson Ridge). It is very likely that seabed moraine evidence for pre-Weichselian ice-sheet margins north of $\sim 60^{\circ} \mathrm{N}$ have been subsequently buried or removed by later glaciations (see below).

- $\quad$ Stage 2 - Large moraines on the outer shelf in the Hebrides Shelf and Central sectors, 10-30 $\mathrm{km}$ inboard from the shelfbreak, record significant stillstands or oscillations of a pre-Late Weichselian ice sheet margin. The innermost MacDonald Formation moraine on the Hebrides Shelf extends to the NW for $\sim 100 \mathrm{~km}$, where it is truncated or overprinted by Otter Bank Formation moraines (of Late Weichselian age) on the outer West Shetland shelf (Stage 3). To the NW of Lewis, the Stage 2 limit is uncertain. At this time the ice sheet probably still 
formed a single coherent shelfbreak-parallel ice-sheet margin, near to its maximal position (= Stage 1 ) at a time of greatly lowered eustatic sea levels. As with Stage 1, clear landform evidence of this pre-Weichselian ice sheet retreat is lacking north of $\sim 60^{\circ} \mathrm{N}$.

- Stage 3 - Moraines on the mid shelf in the Hebrides and Central sectors (North Lewis Ridge and $\mathrm{N}$ Rona Ridges) are correlated with moraines on the outer part of the West Shetland shelf based on morphological and sesimostratigraphic grounds. We infer a broadly lobate ice sheet margin stretching from NW of the Butt of Lewis to the North Rona High. These moraines (or grounding-line features) probably relate to the Minch ice stream front as it stabilized on prominent mid-shelf bathymetric highs. From here this ice sheet limit continues $\sim 70 \mathrm{~km}$ NW to join with the outermost Otter Bank Fm moraines close to the shelfbreak at $\sim 60^{\circ} \mathrm{N}$. The ice-sheet configuration in Stage 3 is not a shelf-parallel one; the ice margin being situated close to the present-day coastline in NW Lewis - which may have hosted ice-free areas very early during deglaciation, consistent with sedimentological evidence of long-lived periglacial conditions (e.g. at Galson Beach; Gordon \& Sutherland, 1993) - but situated at or close to the shelfbreak in the West Shetland sector. Shelf-wide seimostratigraphic relationships suggest that this ice sheet configuration probably occurred during the Late Weichselian Stadial (MIS 2-3), coeval with North Rona deglaciation ca. 25 ka BP (Everest et al., 2013), when eustatic sea levels were still close to their eustatic (LGM) minimum. The subsequent Stages (4-10) are all thought to be of MIS 2 age.

- Stage 4-Large mid-shelf moraine complexes stretching from $\mathrm{N}$ Lewis to the West Shetland Shelf are interpreted to mark a single (long-lived?) Late Weichselian (MIS 2) ice sheet 20-30 $\mathrm{km}$ margin inboard of Stage 3. We join the prominent North Minch Ridge moraine with the Solan Bank Ridge and the outermost, nested, Otter Bank Formation moraine NW of Orkney, which continues NW across the West Shetland Shelf for over $60 \mathrm{~km}$. The ice sheet margin depicted by Stage 4 is developing a more asymmetric form relative to the continental shelfbreak, being $\sim 75 \mathrm{~km}$ from the shelfbreak in the Hebrides Shelf sector but $<20 \mathrm{~km}$ from the shelfbreak on the West Shetland shelf in the extreme north. The ice sheet front was probably stably situated on land close to the present-day coastline in western Lewis at this time. Relative sea levels on the continental shelf NW of Britain at $\sim 20-25$ ka BP are poorly constrained, but numerical glacio-isostatic models place them ca. $100 \mathrm{~m}$ below present on the mid to outer shelf (Lambeck, 1991, 1993). The implication is that the ice sheet margin at this time was probably grounded below sea level to the $\mathrm{N}$ of Lewis, in the Minch, and on the shelf NW of Orkney, but perhaps terminated close to sea level in shallows or on low-lying palaeo-islands in the central sector (around the Solan Bank high). It is likely that deglaciated 
parts of the shelf $\mathrm{W}$ of Lewis and around North Rona would have also been dry land. We suggest that the interaction between topography, relative sea level and ice-sheet grounding dynamics would have been particularly important in determining the rate and style of ice sheet retreat across the shelf at this time.

- Stage 5-Many small and medium-sized moraines occur on the seabed in the central sector inshore of the North Minch-Solan Bank Ridge. We draw a contiguous ice-sheet margin joining the outermost of these, to the W of Cape Wrath, with a moraine system to the E of the Solan Bank High. Unfortunately no firm connection can be made between this moraine and those further $\mathrm{N}$, owing to discontinuous landform evidence, but a link with one of the large nested Otter Bank Formation moraines on the mid shelf is highly likely on geomorphological and seismostratigraphical grounds. Stage 5 has no mapped equivalent in the Minch or $\mathrm{N}$ of $\sim 60^{\circ} \mathrm{N}$ where it has been subsequently truncated or removed by later glacial advances (see below; Stages 6, 7).

- Stage 6 - The NW Sutherland moraines, to the $\mathrm{N}$ of the large Eddrachillis Ridge, are projected to make landfall 5-10 km S of Cape Wrath. We join this ice sheet limit, across the Cape Wrath headland, with the Nun Rock Moraine and its lateral equivalent to the N. We continue this ice sheet margin, around the bathymetric Sule Skerry High, to the $\mathrm{N}$ where it joins with one of the large nested Otter Bank/Stormy Bank Formation moraines on the mid shelf, NW of Orkney. It is not currently possible to firmly trace the Stage 6 ice-sheet limit beyond this point owing to the presence of bedrock at seabed across a large area. Relative sea levels on the continental shelf at this time are not well constrained but were still probably considerably lower ( $\sim 100 \mathrm{~m}$ ) than the present day (Lambeck, 1991), exposing palaeo-islands in the Central sector and on the Hebrides Shelf.

- Stage 7 - The northern Minch, an area of $\sim 2500 \mathrm{~km}^{2}$, is notably lacking in ice-marginal landforms. The next suite of moraines encountered inshore of the North Minch Ridge, in the Hebrides sector, is the major nearshore system defined by the substantial Eddrachillis Ridge and Rubha Coigeach/Greenstone Point/Loch Ewe Moraine complexes. We interpolate a multi-lobed ice sheet margin extending from SW of Loch Ewe (Wester Ross) to the vicinity of Sandwood Bay, in NW Sutherland, where it makes landfall and probably continues across the Cape Wrath headland. The Stage 7 time-equivalent moraine system in the central sector cannot be firmly determined, owing to paucity of onshore data in far NW Sutherland, however correlation with one of the regional moraines between Cape Wrath and Faraidh Head (e.g. RM3, Fig. 12) is most glaciologically plausible. This palaeo-ice sheet margin continues, with three strong inflections, for $150 \mathrm{~km}$ to the $\mathrm{N}$ until it joins the lobate nested 
Otter Bank/Stormy Bank moraine complex NW of Orkney. No firm correlations can be made $\mathrm{N}$ of this point, as moraines are not currently mapped across a large submarine bedrock area on the western Orkney-Shetland Platform, but a continuation to morphologically similar Stormy Bank Formation moraines on the West Shetland shelf is most likely. The NW sector of the BIIS has a strongly asymmetric configuration in Stage 7 - with the ice-sheet margin close to the present-day coastline in mainland NW Scotland, $>120 \mathrm{~km}$ inshore from the shelfbreak; 50 km from the shelfbreak NW of Orkney; and only 20 km from the shelfbreak on the West Shetland Shelf.

- Stage 8 - This stage is defined only by a large lobate moraine complex that truncates (or overprints) the sequence of several regional moraines ( $\mathrm{W}$ of the Reay Moraine) running broadly perpendicular to the north coast of mainland Scotland. It probably represents a short-lived readvance of the ice sheet margin into deeper water west of Orkney. Timeequivalent moraines further $\mathrm{N}$ have most likely been removed by subsequent ice sheet readvances (see Stage 9), although a prominent moraine ridge in the extreme NE of the study area may relate to this stage. Stage 8 may also have a time-equivalent ice sheet margin in the Summer Isles region where numerous seabed moraines record a period of repeated stillstands/readvances during overall ice-sheet retreat prior to 15 ka BP (Bradwell et al., 2008b; Stoker et al., 2009); however, correlation cannot be confirmed with those moraines to the $\mathrm{N}$ of mainland Scotland owing to a lack of chronological constraints. The late-stage readvance (Faraidh Head) moraines offshore Loch Eriboll are also tentatively placed in Stage 8 on the basis of glaciological plausibility (i.e. post-dates Stage 7), though currently no published chronological data exist to confirm this.

- Stage 9 - Represented by the distinctive double-crested lobate Reay Moraine, offshore NW Caithness, this palaeo-ice sheet margin records a relatively large, but possibly short-lived, readvance of the ice sheet up to, and in places over, another prominent regional moraine. Extending $\mathrm{N}$ for $\sim 40 \mathrm{~km}$, the Reay Moraine can be intermittently traced across a wide area of bedrock seabed W of Orkney. We correlate the Reay Moraine with the morphologically similar, double-crested, Westray Loop Moraine - the innermost Stormy Bank Formation moraine, NW of Orkney - the distinctive lobate morphology and seismic architecture of which is also highly suggestive of a dynamic short-lived readvance. Any substantial ice-sheet readvance $(>10 \mathrm{~km})$ is likely to have removed landform evidence of earlier retreat stages in this region, hence the general absence of Stage 8 and intermediate moraines on the West Shetland Shelf and Orkney-Shetland Platform. Time-equivalent Stage 9 moraines to the E of $3^{\circ} 30^{\prime} \mathrm{W}$ are hard to identify with certainty, owing to a large area of bedrock-dominated 
seabed, but a link to the innermost prominent Stormy Bank Formation moraine on the West Shetland shelf is highly likely. To the SE of Orkney we infer an ice sheet margin, broadly concave to the NW, based on the largest seabed moraines identified; this pattern is suggestive of an ice mass centred on the higher ground of the Orkney-Shetland platform. The pattern and morphology of the surrounding de Geer moraine fields strongly support this Orkney-Shetland-centred ice sheet/ice cap geometry. Like Stage 8, Stage 9 may have a timeequivalent ice sheet margin in the Summer Isles region where numerous seabed moraines, and their onshore counterparts, record a period of repeated stillstand/readvance during the final stages of ice sheet decay in NW Scotland (Bradwell et al., 2008b; Stoker et al., 2009). Taken collectively, the carefully reconstructed Stage 9 ice margins represent a considerable reconfiguration during overall ice-sheet decay when the northern sector of the British-Irish Ice Sheet had reorganized into large separate ice masses - one centred over Orkney and Shetland, and one centred over the western Scottish Highlands - with an ice-free corridor between. This is the first time this ice sheet configuration has been proposed for the BIIS.

- Stage 10 - Ice-marginal landforms on the Orkney-Shetland Platform are small, mostly de Geer-type moraines, suggesting relatively rapid retreat of tidewater ice margins. Stage 10 marks one of numerous (?brief) stillstands during overall decay of the ice sheet/cap in its final stages as a separate ice mass centred over Orkney and Shetland. The choice of de Geer moraine to represent this stage is not important; we simply represent a notional stage during final deglaciation - probably around 15-17 ka BP, as determined by TCN exposure ages on Orkney (Phillips et al., 2008). The chosen ice-sheet margin can be traced from the northern mainland of Orkney across the Westray Firth and linked with the prominent de Geer moraines offshore Papa Westray that continue for $20 \mathrm{~km}$ to the NE, and possibly join with those in the Orkney-Shetland Channel. It is currently not possible to firmly identify equivalent Stage 10 moraines to the east of Orkney, owing to a lack of moraine pattern information close to shore. However, we propose that morphologically similar De Geer moraines in comparable water depths to those NE of Papa Westray $(<65 \mathrm{~m})$ support this overall pattern of ice-front retreat back towards Orkney. Broadly time-equivalent ice-sheet moraines in the fjords of the Summer Isles region ( 15 ka BP; Bradwell et al., 2008b; Stoker et al., 2009) record late-stage ice sheet/ice cap oscillations attributed to the final stage of marine-terminating glaciers in northern mainland Scotland.

We suggest that this 10-stage reconstruction of ice sheet retreat, with over 30 intermediate stages (Fig. 18), represents the most detailed and glaciologically plausible pattern of ice sheet retreat for 
the NW sector of the BIIS based on the currently available (Dec. 2013) marine geophysical and geological data. This work refines those previous reconstructions presented for this region by Bradwell et al. (2008a) and Clark et al. (2012).

\subsection{Chronology}

Very few absolute dates currently exist for the formation of the seabed moraine systems around northern Scotland; addressing this forms one of the main objectives of the ongoing Britice-Chrono research project (Clark et al., 2014). Notwithstanding this sparse chronology, most of the glacial landforms identified (excluding Stages 1-2) are believed to relate to the last ice sheet to have covered the British Isles (= Late Weischselian glaciation; ca. 32-15 ka BP) (in agreement with others: e.g. Carr et al., 2006; Bradwell et al., 2008a; Sejrup et al., 2005, 2009; Chiverrell and Thomas, 2010; Clark et al., 2012). We consider this premise to be supported by four key independent lines of evidence:

1) Geomorphological preservation - We consider it unlikely that ice-marginal features (particularly small moraines) would have survived overriding by subsequent glaciation(s). This implies that at least the younger, morphologically more delicate, moraines seen in Stages 5-10, on the inner and mid shelf (Figs 6, 9-17), are almost certainly Late Weichselian in age $(<30 \mathrm{ka} B P)$.

2) Seismostratigraphy - Interpretation of shelf-wide seismic data in the 1970s to 1990s shows a distribution and architecture of Pleistocene glacigenic deposits entirely consistent with advance and retreat of an ice sheet to/from the continental shelf edge, at least on the West Shetland Shelf, during the Late Weichselian (Figs. 3, 19) (Stoker et al., 1993; Fyfe et al., 1993; Stoker et al., 1994; Stoker, 2013).

3) Ice-rafted detritus (IRD) evidence - Marine cores recovered from deep water SW of the Barra-Donegal trough-mouth fan record a strong increase in ice-rafted detritus at $\sim 29 \mathrm{ka} B P$, peaking at $26.5 \mathrm{ka} \mathrm{BP}$ - interpreted to reflect the maximum calving flux from a proximal ice sheet source (Peck et al., 2007; Scourse et al., 2009). This IRD peak is widely associated with maximum stage shelf-edge BIIS glaciation on the Malin Shelf and southern Hebrides Shelf in the Late Weichselian (MIS 2-3).

4) TCN age constraints - A suite of terrestrial cosmogenic nuclide (TCN) analyses from North Rona on the mid shelf date deposition of glacial boulders, and hence indicate ice sheet overriding ca. 25 ka BP (Everest et al., 2013). These data constrain the period of maximum Late Weichselian glaciation (post Stages $1 \& 2$ ) to between 25 ka BP and the sharp IRD 
increase at 29 ka BP. It follows, based on this chronology, that Stage 3 moraines just inshore of North Rona (and the subsequent Stages 4-10) must be younger than 25 ka BP. TCN exposure ages of 15-17 ka BP from low-level sites on mainland Orkney (Phillips et al., 2008) constrain thinning and final decay (Stage 10) of a large ice mass, which we infer to have been centred over Orkney and Shetland. Furthermore, TCN exposure ages from the moraines in the Summer Isles region constrain final onshore retreat of a time-equivalent large ice mass centred over W Scotland at 15 ka BP (Bradwell et al., 2008b; Ballantyne et al., 2009).

Owing to this relatively weak chronology, and the fact that it is currently the subject of a major onshore and offshore research effort (Clark et al., 2014), we deliberately do not attempt to put our reconstruction into a firm chronological context (i.e. by generating dated 'timeslices' or 'isochrones'). However, we have used TCN exposure ages, where they exist, in key onshore localities to place reconstructed palaeo-ice sheet limits within a chronological framework and provide additional independent support for our empirically constrained ice-sheet retreat sequence (Fig. 18).

\section{Summary, comparisons with previous work and some wider implications}

The form and distribution of moraines on the seabed, seen in singlebeam data and seismic subbottom profiles and in more detail in multibeam data, have allowed a new detailed pattern of icesheet retreat to be reconstructed for the continental shelf around northern Scotland. This pattern is one of a shrinking ice sheet undergoing extensive, non-uniform, sector retreat and major configuration change during decay. Our new reconstruction highlights that retreat was not simply concentric but strongly asymmetric - focused in marine-influenced sectors, most notably the Minch, where moraines are absent over $\sim 2500 \mathrm{~km}^{2}$ of seabed. This evidence combined with the presence of well-preserved seabed glacial lineations - ice-stream bedforms - in the central part of the Minch (Stoker \& Bradwell, 2005; Bradwell et al., 2007) suggests deglaciation may have occurred rapidly in this vulnerable bathymetric setting (e.g. Alley et al., 2005; Dowdeswell et al., 2008; Pritchard et al., 2009).

The optimal reconstruction, based on newly available and collated existing data, depicts a single coherent ice-sheet margin initially retreating across the continental shelf broadly from NW to SE in a shelf-edge-parallel fashion (Stages 1-2, Fig. 18). However, it is very likely that these landforms relate to a pre-Weichselian, Mid to Late Pleistocene glaciation of Britain (Stoker et al., 1993; Stoker, 2013). 
Evidence of Late Weichselian glaciation (MIS 2) is seen in Stages $3 \& 4$ and the subsequent deglacial

2

3 stages (5-10). Raised marine sediments at Galson in NW Lewis, first recorded by Baden-Powell (1938), have been interpreted to represent ice-free conditions throughout the last glaciation (Sutherland \& Walker, 1984), although this has been strongly challenged (Hall et al., 2003). Our new reconstruction places the ice sheet margin onshore in NW Lewis at a very early stage during MIS 2 deglaciation (probably 25 ka BP) - entirely consistent with Quaternary geological evidence for periglacial conditions throughout much of the last glacial cycle (Gordon \& Sutherland, 1993). Following Stage 4, regional retreat patterns become focused in sectors - probably driven by changes in bed topography, bathymetry and ice dynamics - with the main part of the Minch $\left(58^{\circ}-58.5^{\circ} \mathrm{N}\right)$ deglaciating in an uninterrupted fashion, perhaps very rapidly, without the formation of moraines. From this point onwards, the ice sheet configuration is substantially and irreversibly changed. With the ice sheet margin close to the coastline in NW Scotland and large ice sheet lobes terminating on the mid-shelf west of Orkney and Shetland (Stages 5-7, Fig. 18), the geometry is strongly asymmetric with respect to the present-day coastline and continental shelfbreak. Continued ice sheet retreat, and geometry change (accompanied by thinning) probably resulted in dynamic shifts in ice centres with a large ice centre focused over the Orkney-Shetland Platform and another large ice centre dominating the West Scottish Highlands. We suggest that physical separation of these ice masses probably occurred between Stages 7-9, with far NW Scotland (Cape Wrath to Foinaven) being revealed relatively early as the ice sheets parted along the spine of high mountains (<750 m asl; Fig. 18). An ice-free corridor(s) connecting NE (Moray Firth) and NW mainland Scotland could have occurred at this time. Continued recession of the northern ice centre was seemingly punctuated by (?short-lived) readvances of the ice margin (Stage 9) before final decay of the ice mass occurred in the vicinity of the Orkney Islands (Stage 10, Fig. 18) (ca. 15-17 ka BP; Phillips et al., 2008). A separate, but relatively large local ice centre probably also existed on Shetland at this time (cf. Golledge et al., 2008; Hall, 2013). The currently available evidence suggest that the southern ice centre, focused over the western Scottish Highlands, had retreated onshore by 15 ka BP (Stage 10, Fig. 18), at least in the Assynt, Summer Isles and Wester Ross regions (Bradwell et al., 2008b; Ballantyne et al., 2009); whereafter its behaviour and final decay pattern is still the subject of debate (cf. Stoker et al., 2009; Finlayson et al., 2011; Ballantyne \& Stone, 2010).

In their comprehensive ice-sheet-wide summary, combining all relevant chronological and geomorphological evidence, Clark et al. (2012) show schematic, albeit generalised, reconstructions of ice-sheet retreat at key intervals during deglaciation (their Figs. 17, 18). Focusing on northern Scotland they propose time-equivalent, contiguous, ice-sheet limits (isochrones) with some similarities to the 3-stage reconstructions presented by Bradwell et al. (2008a) and the more 
detailed multi-stage reconstructions presented here (Fig. 18). Most notable similarities are: the shelf-edge configuration at maximum stage (isochrone '27 ka' in Clark et al., 2012; but note the PreWeichselian age for Stages 1-2 (this study)); the general west to east retreat of ice on the Hebrides and Shetland shelves, with proportionately more ice loss in the south relative to the north (isochrones '27-17 ka'); the large open embayment in the Minch (isochrones '19-17 ka'); and the presence of separate late-stage ice centres on Orkney (and Shetland) and mainland Scotland (by isochrone '16 ka'). Where the reconstructions (Clark et al. 2012 and this study) significantly diverge, however, is in the configuration changes that occur following their 'isochrone 17 ka' (broadly equivalent to our Stage 4-5). We envisage that the ice sheet 'unzipped' along the spine of high ground in NW Sutherland relatively early during deglaciation, radically altering the ice sheet geometry of both subsequent ice centres (referred to hereafter as northern and southern 'ice sheets'). Moraine patterns suggest that this was followed by continued eastward retreat of the northern ice sheet's Atlantic margin, almost perpendicular to the north coast of mainland Scotland, towards the Orkney-Shetland Platform (Stages 6-9). At the same time, the geological evidence suggests the southern ice sheet's margin remained relatively stable in the eastern Minch, close to the present-day coastline (Stage 6-9), but that thinning and retreat from north to south forced the terrestrial ice sheet margins back towards the main massifs of the Western Scottish Highlands. We find no evidence for an ice sheet limit adjacent and parallel to the north coast of mainland Scotland (cf. Clark et al., 2012; with this study, Fig. 18). These key differences in ice-sheet retreat geometry, rate and style, between previously published work (Clark et al., 2012) and our new study, may be vitally important when seeking to chronologically constrain and refine the pattern of British-Irish Ice Sheet retreat using geological samples from onshore and offshore (e.g. using TCN, OSL, C-14, etc.). Alongside others, we seek to test and develop these hypotheses - part of ongoing work into the rate and style of marine-influenced ice-sheet decay around the British Isles.

\section{Acknowledgments}

This research was funded by BGS-NERC (Energy \& Marine Geology Directorate) and is a scientific contribution to the MAREMAP programme. Bob Gatliff, Alan Stevenson and John Howe are thanked for organizing the conference (Seabed Mapping in the $21^{\text {st }}$ century) and for inviting TB to contribute to it. This work was largely undertaken prior to the start of the NERC-funded Britice-Chrono project, but has benefitted subsequently from conversations with several consortium members (most notably Chris Clark). We thank the journal reviewers for their comments and Rhys Cooper for 
processing MBES data. Vicki Hammond is thanked for editing the final MS. Multibeam echosunder data provided by MCA (UKHO) who are gratefully acknowledged. MCA survey data is Crown Copyright. Singlebeam bathymetry data is from the Olex database, accessed under license by BGS/NERC. Published with the permission of the Executive Director, BGS (NERC).

\section{References}

Alley, R.B., Clark, P.U., Huybrechts, P. \& Joughin, I. 2005. Ice-sheet and sea-level changes. Science 310, 456-460.

Andrews, I.J., Long, D., Richards, P.C., Thomson, A.R., Brown, S., Chesher, J.A. \& McCormac, M. 1990. United Kingdom Offshore Regional Report: The Geology of the Moray Firth. London: HMSO for the British Geological Survey. 93 pp.

Ballantyne, C.K., Schnabel, C., Xu, S. 2009: Readvance of the last British-Irish Ice Sheet during Greenland Interstade 1 (GI-1): the Wester Ross readvance, NW Scotland. Quaternary Science Reviews 28, 783-789.

Ballantyne, C.K. \& Stone, J.O. 2010. Did large ice caps persist on low ground in NW Scotland during the Lateglacial Interstade? Journal of Quaternary Science 27, 297-306.

Baden-Powell, D.F.W. 1938. On the glacial and interglacial marine beds of North Lewis. Geological Magazine 75: 395-409.

Benn, D.I., Kirkbride, M.P., Owen, L.A. \& Brazier, V. 2003. Glaciated valley landsystems. In Evans, D.J.A. (ed.) Glacial Landsystems, 372-406. London: Arnold.

Bennett, M.R. \& Boulton, G.S., 1993. Deglaciation of the Younger Dryas or Loch Lomond Stadial icefield in the northern Highlands, Scotland. Journal of Quaternary Science 8, 133-146.

British Geological Survey (BGS), 1984. Orkney. Sea bed sediments and Quaternary geology. 1:250,000 map series. British Geological Survey, Keyworth, Nottingham.

British Geological Survey (BGS), 1989. Sutherland. Sea bed sediments and Quaternary geology. 1:250,000 map series. British Geological Survey, Keyworth, Nottingham.

British Geological Survey (BGS), 1994. Rona. Sea bed sediments and Quaternary geology. 1:250,000 map series. British Geological Survey, Keyworth, Nottingham.

British Geological Survey (BGS), 1995. Lewis. Sea bed sediments and Quaternary geology. 1:250,000 map series. British Geological Survey, Keyworth, Nottingham.

British Geological Survey (BGS), 2012. Bedrock and Superficial Geology of the United Kingdom. DIGMAP50k. Digital geological map and database. British Geological Survey, Keyworth, Nottingham. 
British Geological Survey (BGS), 2013. Bedrock and Quaternary Geology of the United Kingdom Continental Shelf. DIGMAP50k. Digital geological map and database. British Geological Survey, Keyworth, Nottingham.

Bradwell, T. 2013: Identifying palaeo-ice-stream tributaries on hard beds: mapping glacial bedforms and erosion zones in NW Scotland. Geomorphology 201: 397-414.

Bradwell, T., Stoker, M.S., Golledge, N.R., Wilson, C.K., Merritt, J.W., Long, D., Everest, J.D., Hestvik, O.B., Stevenson, A.G., Hubbard, A.L., Finlayson, A.G. \& Mathers, H.E. 2008a. The northern sector of the last British Ice Sheet: Maximum extent and demise. Earth-Science Reviews 88, 207-226.

Bradwell, T., Fabel, D., Stoker, M.S., Mathers, H., Mchargue, L. \& Howe, J.A. 2008b. Ice caps existed throughout the Lateglacial Interstadial in northern Scotland. Journal of Quaternary Science 23, 401407.

Bradwell, T., Stoker, M. \& Larter, R. 2007. Geomorphological signature and flow dynamics of the Minch palaeo-ice stream, NW Scotland. Journal of Quaternary Science 22, 609-617.

Carr, S.J., Holmes, R., van der Meer, J.J.M., \& Rose, J. 2006. The Last Glacial Maximum in the North Sea Basin: micromorphological evidence of extensive glaciation. Journal of Quaternary Science 21: 131-153.

Chiverrell, R.C. \& Thomas, G.S.P. 2010. Extent and timing of the Last Glacial Maximum (LGM) in Britain and Ireland: a review. Journal of Quaternary Science 25: 535-549.

Chiverrell, R. C., Thrasher, I. M., Thomas, G. S. P., Lang, A., Scourse, J. D., van Landeghem, K. J. J., Mccarroll, D., Clark, C. D., Cofaigh, C. Ó., Evans, D. J. A. \& Ballantyne, C. K. 2013. Bayesian modelling the retreat of the Irish Sea Ice Stream. Journal of Quaternary Science 28: 200-209.

Clark, C.D., Fabel, D., O'Cofaigh, C., Chiverrell, R., Scourse, J., Hindmarsh, R.C.A., Bradwell, T. \& 25 others. 2014. BRITICE-CHRONO: Constraining rates and style of marine-influenced ice sheet decay. Quaternary Revolutions: Quaternary Research Association, Annual Discussion Meeting, London. Abstract Volume, p16.

Clark, C.D., Evans, D.J.A., Khatwa, A., Bradwell, T., Jordan, C.J., Marsh, S.H., Mitchell, W.A. \& Bateman, M.D., 2004. BRITICE: map and GIS database of landforms and features related to the last British Ice Sheet. Boreas 33, 359-375.

Clark, C.D., Hughes, A.L.C., Greenwood, S.L., Jordan, C. \& Sejrup, H.P. 2012. Pattern and timing of retreat of the last British-Irish Ice Sheet. Quaternary Science Reviews 44, 112-146.

Davison, S., 2005. Reconstructing the Last Pleistocene (Late Devensian) Glaciation on the Continental Margin of Northwest Britain. Unpublished PhD thesis. University ofEdinburgh.

Dawson, A.G. 1984. Quaternary sea-level changes in western Scotland. Quaternary Science Reviews 3, 345-368.

Dowdeswell, J.A., Ottesen, D., Evans, J., Ó Cofaigh, C. \& Anderson, J.B., 2009. Submarine glacial landforms and rates of ice-stream collapse. Geology 36, 819-822.

Dunlop, P., Shannon, R., McCabe, M., Quinn, R. \& Doyle, E. 2010. Marine geophysical evidence for ice sheet extension and recession on the Malin Shelf: New evidence for the western limits of the British-Irish Ice Sheet. Marine Geology 276, 86-99. 
Evans D.J.A., Clark C.D. \& Mitchell W.A. 2005. The last British Ice Sheet: a review of the evidence utilised in the compilation of the Glacial Map of Britain. Earth-Science Reviews 70: 253-312.

Evans, D.J.A. \& Rea, B.R., 2003. Surging glacier landsystem. In Evans, D.J.A. (ed.) Glacial Landsystems, 259-289. London: Arnold.

Everest, J.D., Bradwell, T., Stoker, M.S. \& Dewey, S. 2013. New age constraints for the maximum extent of the last British-Irish Ice Sheet (NW Sector). Journal of Quaternary Science 28, 2-7.

Finlayson, A.G., Golledge, N.R., Bradwell., T. \& Fabel., D. 2011. Evolution of a Lateglacial mountain ice cap in Northern Scotland. Boreas 40, 536-554.

Finlayson, A., Fabel, D., Bradwell, T., Sugden, D.E. 2014. Growth and decay of a marine-terminating sector of the last British-Irish Ice Sheet: a geomorphological reconstruction. Quaternary Science Reviews 83, 28-45.

Fyfe, J.A., Long, D. \& Evans, D. 1993. United Kingdom offshore regional report: the geology of the Malin-Hebrides Sea area. London: HMSO for the British Geological Survey. 92pp.

Gibbard, P.L. \& Clark, C.D. 2011. Pleistocene Glaciation Limits in Great Britain. Developments in Quaternary Science 15, 75-93.

Golledge, N.R., Finlayson, A., Bradwell, T. \& Everest, J.D., 2008. The last glaciation of Shetland, North Atlantic. Geografiska Annaler 90A, 37-53.

Gordon, J.E. \& Sutherland, D.G. 1993. Quaternary of Scotland. London: Chapman and Hall. 695pp.

Greenwood, S.L. \& Clark, C.D., 2009. Reconstructing the last Irish Ice Sheet. 2: a geomorphologically driven model of ice sheet growth, retreat and dynamics. Quaternary Science Reviews 28, 3101-3123.

Hall, A.M. 2013. The last glaciation of Shetland: local ice cap or invasive ice sheet? Norwegian Journal of Geology 93, 229-242.

Hall, A.M., Peacock, J.D. \& Connell, E.R. 2003. New data for the Last Glacial Maximum in Great Britain and Ireland: a Scottish perspective on the paper by Bowen et al. (2002). Quaternary Science Reviews 22, 1551-1554.

Howe, J.A., Dove, D., Bradwell, T. \& Gaferia, J. 2012. Submarine gemorphology and glacial history of the Sea of the Hebrides. Marine Geology 315-318, 64-76.

Hubbard, A., Bradwell, T., Golledge, N.R., Hall, A.M., Patton, H., Sugden, D.E.,Cooper, R., Stoker, M.S., 2009. Dynamic cycles, ice streams and their impact on the extent, chronology and deglaciation of the British-Irish Ice Sheet. Quaternary Science Reviews 28, 758-776.

Hughes, A.L.C., Clark, C.D., \& Jordan, C.J. 2010. Subglacial bedform map of Britain. Journal of Maps 2010, 543-563.

Hughes, A.L.C., Greenwood, S.L. \& Clark, C.D. 2011. Dating constraints on the Last British-Irish ice sheet: a map and database. Journal of Maps 2011, 156-183.

IPCC, 2013. Climate Change 2013: The Physical Science Basis. Contribution of Working Group I to the Fifth Assessment Report of the Intergovernmental Panel on Climate Change (eds.) Stocker, T.F. et al. Cambridge: Cambridge University Press. 
Kenyon, N.H. \& Stride, A.H. 1970. The tide-swept continental shelf sediments between the Shetland Isles and France. Sedimentology 14: 159-173.

3

4

5

6

Lambeck, K. 1991. Glacial rebound and sea-level change in the British Isles. Terra Nova 3: 379-389.

Lambeck K. 1993. Glacial Rebound of the British Isles-II. A high-resolution, high-precision model. Geophysical Journal International 115: 960-990.

Lindén, M. \& Möller, P., 2005. Marginal formation of De Geer moraines and their implications to the dynamics of grounding-line recession. Journal of Quaternary Science 20, 113-133.

Milne, G.A., Shennan, I., Youngs, B.A.R., Waugh, A.I., Teferle, F.N., Bingley, R.M.,Bassett, S.E., Cuthbert-Brown, C. \& Bradley, S.L. 2006. Modelling the glacial isostatic adjustment of the UK region. Philosophical Transactions of the Royal Society 364: 931-948.

O' Cofaigh, C. 2012. Ice sheets viewed from the ocean: the contribution of marien science to understanding modern and past ice sheets. Philosophical Transactions of the Royal Society A 370, 5512-5539.

O' Cofaigh, C., Dunlop, P. \& Benetti, S., 2012. Marine geophysical evidence for Late Pleistocene ice sheet extent and recession off northwest Ireland, Quaternary Science Reviews 44, 147-159.

Ottesen, D. \& Dowdeswell, J.A. 2006. Assemblages of submarine landforms produced by tidewater glaciers in Svalbard. Journal of Geophysical Research 111, F01016.

Peck, V.L., Hall, I.R., Zahn, R., Grousset, F. \& Hemming, S.R. 2007. The relationship of Heinrich events and their European precursors over the past $60 \mathrm{ka}$ BP: a multi-proxy ice-rafted debris provenance study in the North East Atlantic. Quaternary Science Reviews 26, 862-875.

Peltier,W.R. \& Fairbanks, R.G. 2006. Global glacial ice volume and Last Glacial Maximum duration from an extended Barbados sea level record. Quaternary Science Reviews 25, 3322-3337.

Phillips, W.M., Hall, A.M., Ballantyne, C.K., Binnie, S., Kubik, P.W. \& Freeman, S. 2008. Extent of the last ice sheet in northern Scotland tested with cosmogenic 10Be exposure ages. Journal of Quaternary Science 23, 101-107.

Pritchard, H.D., Arthern, R.J., Vaughan, D.G. \& Edwards, L.A. 2009. Extensive dynamic thinning on the margins of the Greenland and Antarctic ice sheets. Nature 461, 971-975.

Ritchie, J.D., Ziska, H., Johnson, H. \& Evans, D. (eds.) 2011. Geology of the Faroe-Shetland Basin and adjacent areas. British Geological Survey Research Report RR/11/01, Jarðfeingi Research Report $\mathrm{RR} / 11 / 01$.

Rydningen,T.A., Vorren, T.O., Laberg, J.S. \& Kolstad, V., 2013. The marine-based NW Fennoscandian ice sheet: glacial and deglacial dynamics as reconstructed from submarine landforms. Quaternary Science Reviews 86, 126-141.

Schoof, C. 2012. Marine ice sheet instability. Journal of Fluid Mechanics 698, 62-72.

Scourse, J.D., Haapaniemi, A.I., Colmenero-Hidalgo, E., Peck, V.L., Hall, I.R., Austin,W.E.N., Knutz, P.C. \& Zahn, R., 2009. Growth, dynamics and deglaciation of the last British-Irish ice sheet: the deep-sea ice-rafted detritus record. Quaternary Science Reviews 28, 3066-3084.

Sejrup, H.P., Hjelstuen, B.O., Dahlgren, K.I.T., Haflidason, H., Kuijpers, A., Nygard, A.,Praeg, D., Stoker, M.S. \& Vorren, T.O., 2005. Pleistocene glacial history of the NW European continental margin. Marine and Petroleum Geology 22, 1111-1129. 
Sejrup, H.P., Nygard, A., Hall, A.M. \& Haflidason, H., 2009. Middle and Late Weichselian (Devensian) glaciation history of south-western Norway, North Sea and eastern UK. Quaternary Science Reviews 28, 370-380.

Shaw, J., Piper, D.J.W., Fader, G.B.J., King, E.L., Todd, B.J., Bell, T., Batterson, M.J. \& Liverman,D.G.E., 2006. A conceptual model of the deglaciation of Atlantic Canada. Quaternary Science Reviews 25, 2059-2081.

Shennan, I., Bradley, S.,Milne, G., Brooks, A., Bassett, S. \& Hamilton, S. 2006. Relative sea-level changes, glacial isostatic modelling and ice-sheet reconstructions from the British Isles since the Last Glacial Maximum. Journal of Quaternary Science 21, 585-599.

Sissons, J.B. 1987. Shorelines and Isostasy in Scotland. In Smith, D.E. and Dawson, A.G. (eds.) Shorelines and Isostasy, 209-225. London: Academic Press.

Stoker, M.S. 1990. Glacially influenced sedimentation on the Hebridean slope, northwestern United Kingdom continental margin. In Dowdeswell, J.A. \& Scourse, J.D. (eds.) Glacimarine Environments: Processes and Sediments. 349-362. London: Geological Society of London, Special Publication 53.

Stoker,M.S. 1995. The influence of glacigenic sedimentation on slope-apron development on the continental margin off Northwest Britain. In Scrutton, R.A., Stoker, M.S., Shimmield, G.B., Tudhope, A.W. (eds.) The Tectonics, Sedimentation and Paleoceanography of the North Atlantic Region, 159177. London: Geological Society of London, Special Publications.

Stoker, M.S. 2013. Cenozoic sedimentary rocks. In: Hitchen, K, Johnson, H. \& Gatliff, R.W. (eds) Geology of the Rockall Basin and adjacent areas. British Geological Survey Research Report $\mathrm{RR} / 12 / 03$.

Stoker, M.S. \& Holmes, R. 1991. Submarine end-moraines as indicators of Pleistocene ice-limits off north-west Britain. Journal of the Geological Society, London 148, 431-434.

Stoker, M.S. \& Bradwell, T. 2005. The Minch palaeo-ice stream, NW sector of the British-Irish ice sheet. Journal of the Geological Society, London 162, 425-428.

Stoker, M.S. \& Bradwell, T. 2011. The Quaternary Geology of the Summer Isles Region. Sheet Explanation. Keyworth: British Geological Survey. 36pp.

Stoker, M.S. \& Varming, T. 2011. Cenozoic (sedimentary). In: Ritchie, J.D., Ziska, H., Johnson, H. \& Evans, D. (eds.) Geology of the Faroe-Shetland Basin and adjacent areas. British Geological Survey Research Report RR/11/01, Jarðfeingi Research Report RR/11/01.

Stoker, M.S., Hitchen, K. \& Graham, C.G. 1993. United Kingdom offshore regional report: the geology of the Hebrides and West Shetland shelves, and adjacent deep-water areas. London: HMSO for the British Geological Survey. 150pp.

Stoker, M.S., Leslie, A.B., Scott, W.D., Briden, J.C., Hine, N.M., Harland, R., Wilkinson, I.P., Evans, D. \& Ardus, D.A. 1994. A record of late Cenozoic stratigraphy, sedimentation and climate change from the Hebrides Slope, NE Atlantic Ocean. Journal of the Geological Society, London, 151, 235-249.

Stoker, M.S., Bradwell, T., Wilson, C., Harper, C., Smith, D. \& Brett, C. 2006. Pristine fjord landsystem revealed on the seabed in the Summer Isles region, NW Scotland. Scottish Journal of Geology, 42: 89-99. 
Stoker, M.S., Bradwell, T., Howe, J.A., Wilkinson, I.M. \& Mcintyre, K. 2009. Lateglacial ice cap

2 dynamics in NW Scotland: evidence from the fjords. Quaternary Science Reviews 28, 3161-3184.

3 Stoker, M.S., Balson, P.S., Long, D. \& Tappin, D.R. 2011a. An overview of the lithostratigraphical

4 framework for the Quaternary deposits on the United Kingdom continental shelf. British Geological

5 Survey Research Report, RR/11/03. Keyworth: British Geological Survey.

6 Stoker, M.S., McMillan, A.A. \& Waters, C.N. 2011b. Quaternary Stratigraphical Chart: Northern

7 Britain. British Geological Survey.

8 Sutherland, D.G. 1984. The Quaternary deposits and landforms of Scotland and the neighbouring

9 shelves: a review. Quaternary Science Reviews 3, 157-254.

10 Sutherland, D.G. \& Walker, M.J.C. 1984. A Late Devensian ice-free area and possible interglacial site 11 on the Isle of Lewis, Scotland. Nature 309, 701-703. Shelf: evidence for Late Wisconsinan ice-sheet dynamics and implications for the formation of De 
2 Figure 1: Extent of study area in northern United Kingdom, showing general topography and bathymetry around northern Scotland. Bathymetry coloured to emphasise depth variations on the continental shelf; water depths off the continental shelf $(>200 \mathrm{~m})$ are not shown. Bathymetric features in italic font; islands and headlands in roman font.

6

Figure 2: Echosounder bathymetry data coverage on the UK continental shelf within the study area (as of December 2013). Both singlebeam and multibeam data sets were used in this work. Singlebeam echosounder data are part of a global dataset managed and compiled by Olex AS (Norway) and licensed for scientific research. Multibeam echosounder data were primarily collected by the Maritime and Coastguard Agency between 2005 and 2011 and form part of ongoing UK Hydrographic Office surveys in UK waters.

Figure 3: (A). Distribution of Quaternary Formations on the NW UK Continental shelf, determined from seismostratigraphy and seabed cores (modified from Stoker et al., 1993). Where the Quaternary succession is thin, patchy or cannot be resolved in seismic profiles it remains undifferentiated; this results in some artificial boundaries. Inset maps show (B) available marine geophysical data and $(C)$ seabed cores on which these original interpretations were made. Black lines are single channel seismic profiles mostly collected by the British Geological Survey between 1970 and 1990. Green dots are existing BGS boreholes (variable depth penetration, typically 20-300 m); orange dots are BGS vibrocores (max. $6 \mathrm{~m}$ penetration).

Figure 4: Quaternary stratigraphy of the (A) West Shetland Shelf and (B) Hebrides Shelf, derived from seismic profiles (from Stoker et al., 1993). (C) Schematic showing stratigraphic relationship between Pleistocene units on the mid-outer shelf, highlighting their angular discordance. See Figure 1 for lines of section.

Figure 5: Bathymetry of study area. Image (top left) shows shelf-wide digital surface model compiled from various bathymetric datasets (singlebeam and multibeam); surface model is hillshaded with illumination from the NW. These data have been used to map the seabed glacial geomorphology around northern Scotland in detail. Bathymetric transects (1-10) show cross-profile (2D) morphology of selected ridges on the continental shelf (named and described in this study). Long dashed lines show boundaries between 3 sub-areas, defined for convenience: (i) The Minch and Hebrides Shelf; (ii) Central Sector (iii); West Shetland Shelf and Orkney-Shetland Platform.

Figure 6: Distribution of all ice-marginal landforms mapped in this study on the NW UK continental shelf. Areas of bedrock at seabed also shown. For more detailed geomorphology of sub-areas see Figures 6-15. 
2 Figure 7: (A) Hill-shaded multibeam bathymetry data, and (B) bathymetric cross profiles of North 3 Minch Ridge on the mid shelf, $\sim 40 \mathrm{~km} \mathrm{NW}$ of Cape Wrath, in present-day water depths ca. $80 \mathrm{~m}$. 4 Note the irregular pitted surface, suggestive of iceberg keel marks and scours. Contains Maritime 5 and Coastguard Agency MBES data.

Figure 8: BGS sparker profile (upper panel) and seismostratigraphic interpretation (lower panel) of the Eddrachillis Ridge, eastern part of the Minch. This large 30-40 m high ridge and the smaller ridges inboard to the SE have not been formally defined within the existing Quaternary stratigraphic framework. The collective evidence suggests they are relatively late-stage (MIS2) subaqueous moraines recording grounded ice-sheet margin oscillations offshore mainland NW Scotland. For line of section see Figure 1.

Figure 9: Seabed moraines in the Summer Isles region, NW Scotland (mapped and studied previously by Stoker et al., 2006, 2009; Bradwell et al., 2008). (A) Hill-shaded multibeam bathymetric image showing suite of transverse ridges (moraines) between Tanera Mor and Carn nan Sgeir. [Multibeam echosounder data acquisition by BGS]. (B) Hill-shaded multibeam bathymetric image of seabed moraines $\sim 10 \mathrm{~km}$ NW of Tanera Mor. Note the small delicate De Geer moraines $(\mathrm{m})$ overprinting the larger (older) set of regional moraines (RM). Location of bathymetric profile (lower panel) shown by line. (C) BGS seismic reflection (boomer) profile of subaqueous moraines between Tanera Mor and Carn nan Sgeir. Note the asymmetric cross profile. Rockhead/diamicton contact mapped where acoustically resolvable. Line of seismic profile shown in A. SBM - seabed multiple; BT - bottom tracking pulse (modified from Bradwell et al., 2008).

Figure 10: Seabed moraines in the central sector, SW of Nun Rock High. (A) Hill-shaded multibeam bathymetry data showing area of dense seabed ridges interpreted as ice-sheet moraines. (B) Outline goemorphological map of seabed ridges. Note how the morphology of ZZM (zigzag moraine) overprints adjacent (older) ridges, suggesting a readvance of the ice sheet margin. (C) Hill-shaded greyscale bathymetric surface model, illuminated from the NW, used to map ridge morphology and crestlines in detail. (D) Bathymetric cross profiles of closely spaced, well developed seabed moraines SW of Nun Rock; profile lines shown in A. For bathymetric colour ramp see Fig. 7. Contains Maritime and Coastguard Agency MBES data.

Figure 11: Seabed moraines in the central sector, $S$ of Nun Rock High. (A) Hill-shaded multibeam bathymetric image showing suites of transverse ridges between Nun Rock and Cape Wrath. (B) Outline geomorphological map of ridges (large and small) interpreted as ice sheet moraines; stipple is bedrock at seabed. NRM - Nun Rock Moraine; RM - regional moraines 1; m1, m2 - smaller recessional moraines. (C) Bathymetric transects perpendicular to ridge crests showing cross profile (2D) morphology of selected ridges. Depths and distances in metres. (D) BGS seismic reflection 
1 (airgun) profile across seabed moraines $S$ of Nun Rock. Line of profile shown in A \& B. Note the 2 Pleistocene sediment package thickening in the vicinity of the Nun Rock moraine; sediment cover is 3 thin or absent in places to the east. For bathymetric colour ramp see Fig. 7. Contains Maritime and 4 Coastguard Agency MBES data.

5

6

7

8

Figure 12: Seabed moraines off the Sutherland coast due $N$ of Faraidh head. (A) Hill-shaded multibeam bathymetric image showing the area of complex multi-phase glacial geomorphology. (B) Outline geomorphological map of transverse seabed ridges interpreted as ice-marginal landforms (moraines). Larger, older ridges (grey) are regional moraines (RM) relating to ice sheet retreat generally from west to east; smaller, younger ridges (black, FHM) relate to a later phase of advance and retreat of an ice mass sourced to the $S$, in NW Sutherland. (C) BGS seismic reflection (airgun) profile across seabed moraines off Faraidh Head. Line of survey shown in A \& B. Pleistocene sediment package is locally up to $20 \mathrm{~m}$ thick in ridges although sequence is undivided. Exact stratigraphic relationship between Regional Moraines and Faraidh Head Moraines is uncertain owing to low resolution of airgun profile; however, geomorphology shows the latter, more pronounced, ridges superimposed on the former, broader ridges, in places. FHM - Faraidh Head Moraines; RM Regional Moraines; SBM - Seabed multiple. For bathymetric colour ramp see Fig. 6. Contains Maritime and Coastguard Agency MBES data.

Figure 13: Seabed moraines off the $N$ Caithness coast. (A \& B) Hill-shaded singlebeam echosounder bathymetric images (Olex dataset); arrows highlight prominent arcuate sediment ridge (RR) abutting or overprinting older more subdued forms (MR). (A) Illuminated from the NE; (B) illuminated from the NW. (C) BGS seismic reflection (airgun) profile across seabed offshore Caithness. Line of survey shown in A perpendicular to crest of ridges. Note the Pleistocene sediment package thickening to form a distinctive double crested ridge - the Reay Moraine. Steep-sided transverse sediment ridges to the $E$ are similar to large Holocene sandwaves seen elsewhere on the continental shelf; although seismic reflection data suggest some may be draped over Pleistocene (glacial) sediment cores. RR Reay Ridge; MR - Melvich Ridge; SBM - Seabed multiple.

Figure 14: Seabed moraines on the mid-shelf NW of Orkney. (A) Hill-shaded echosounder bathymetric surface model illuminated from the NW; dashed line shows join between singlebeam and multibeam data. (B) Hill-shaded multibeam bathymetry data showing the prominent Westray Loop Moraine (WLM) complex in detail (area of image shown in A). (Lower panel) Bathymetric profiles perpendicular to ridge complex showing different cross profile (2D) morphology of moraine at various points. Depths and distances in metres. (C) Regional bathymetric transect showing depth profile of mid-shelf. Note the reverse (inshore deepening) slope and location of main moraine complexes. (D) BGS seismic reflection (sparker) profile across Westray Loop Moraine and adjacent basin. Line of seismic profile shown in A. Note the disrupted reflectors within the moraine ridge possible evidence of glaciotectonic deformation. Contains Maritime and Coastguard Agency MBES data. 
Figure 15: Seabed moraines on the western flank of the Orkney-Shetland Platform. (A) Hill-shaded multibeam bathymetry data showing suite of long transverse ridges $W$ of Westray. (B) Outline map of transverse seabed ridges interpreted as subaqueous recessional moraines. Red arrow indicates direction of ice-sheet retreat inferred from moraine morphology. Bedrock at seabed is stippled. (C) Oblique view of seabed moraines, looking NW, showing line of bathymetric profile; generated in Fledermaus software. (Lower panel) Bathymetric profile (in metres) perpendicular to crestline of moraines along line $X-X^{\prime}$. (D) Morphometric analysis of moraines (from $W$ to $E ; 40$ cross profiles). Grey profiles show end members: smallest (and most asymmetric) and largest (almost symmetrical) ridge. Red profile is more typical. [Note: other profiles removed to aid clarity.] (E) Extract of seabed slope model (derived from bathymetric xyz data) for area shown in A. Warm colours are steeper slopes. Note the generally higher slope angles on east-facing slopes, highlighting moraine asymmetry. Steep west-facing slopes occur locally. [Diagonal stripes are data and processing artefacts.] Contains Maritime and Coastguard Agency MBES data.

Figure 16: Seabed moraines on the Orkney-Shetland Platform. (A) Hill-shaded multibeam bathymetry data showing suites of transverse ridges in the North Sound, offshore Papa Westray, Orkney. Onshore elevation model: hill-shaded NEXTMap Britain digital surface model. (B) Summary map of transverse seabed ridges interpreted as subaqueous recessional (de Geer) moraines (black, grey lines). Red arrows indicate direction of ice-sheet retreat inferred from moraine morphology. Large sandbanks are shown in blue. Bedrock at seabed is stippled. Note how the moraines chart retreat in two different directions, suggesting separation of a palaeo-ice front around submerged bedrock highs (marked). Dashed line shows extent of multibeam data. (C) Bathymetric profiles (in metres) perpendicular to crestline of moraines showing typical slope asymmetry. Profile lines are shown in A. Contains Maritime and Coastguard Agency MBES data.

Figure 17: Seabed moraines SE of Orkney. (A) Hill-shaded multibeam bathymetry data showing suite of transverse ridges $\sim 40 \mathrm{~km} E$ of Duncansby Head, Outer Moray Firth. (B) Summary map of transverse seabed ridges interpreted as subaqueous recessional (de Geer) moraines (black lines). Red arrow indicates direction of ice-sheet retreat inferred from moraine morphology. Note the absence of moraines in deeper water areas $(>80 \mathrm{~m})$. (C) Bathymetric profile (in metres) perpendicular to crestline of moraines showing typical slope asymmetry; profile line shown in $A$. (D) Oblique view of seabed $\sim 25 \mathrm{~km}$ ENE of moraine suite in A, looking $\mathrm{N}$; shows moraines and marine bedforms at strongly different, almost perpendicular, orientations. Lines of bathymetric profiles also shown. (Lower panel) Bathymetric profiles (in metres) perpendicular to transverse features showing the markedly different cross profile of de Geer moraines (steeper slopes; greater relief) vs. marine bedforms. Note different scales on $\mathrm{x}$ and $\mathrm{y}$ axes. Contains Maritime and Coastguard Agency MBES data. 
1 Figure 18: Reconstructed ice-sheet margins around northern Scotland based on new 2 geomorphological seabed mapping. Coloured lines show key ice-margin positions (Stages 1-10) 3 during retreat. Solid lines are based on landform evidence (moraines); dashed lines are inferred or 4 extrapolated. Key published terrestrial cosmogenic nuclide (TCN) exposure ages (from Phillips et al., 5 2008, Bradwell et al. 2008, Everest et al. 2013) are also shown. TCN ages are means of several 6 samples. Note the strongly asymmetric pattern of deglaciation relative to the shelfbreak 7 exemplified in Stage 7 - with ice-sheet retreat back to the coastline in NW mainland Scotland, at the 8 same time as ice-sheet oscillations on the mid shelf $W$ of Orkney and on the outer shelf $W$ of 9 Shetland. This reconstructed pattern of British-Irish Ice Sheet retreat differs from current models (cf. 10 Bradwell et al., 2008; Clark et al., 2012), and points to a large ice mass centred over Orkney-Shetland 11 at a relatively late stage during Weichselian deglaciation. This model forms a new framework which 12 will be tested by future work.

Figure 19: Distribution of seabed moraines mapped from echosounder bathymetry data (this study) overlaid on the distribution of Quaternary Formations on the NW UK Continental shelf, mapped from seismostratigraphy and borehole data (modified from Stoker et al., 1993). Ice-marginal landforms are from Figure 5; grey polygons (large); thin black lines (small) moraines. Note the clear agreement between the two independently derived maps: the generally eastward-younging Pleistocene sequence, north of $59^{\circ} \mathrm{N}$, matches well with the pattern of seabed moraines indicating predominantly eastward or south-eastward ice sheet retreat. 


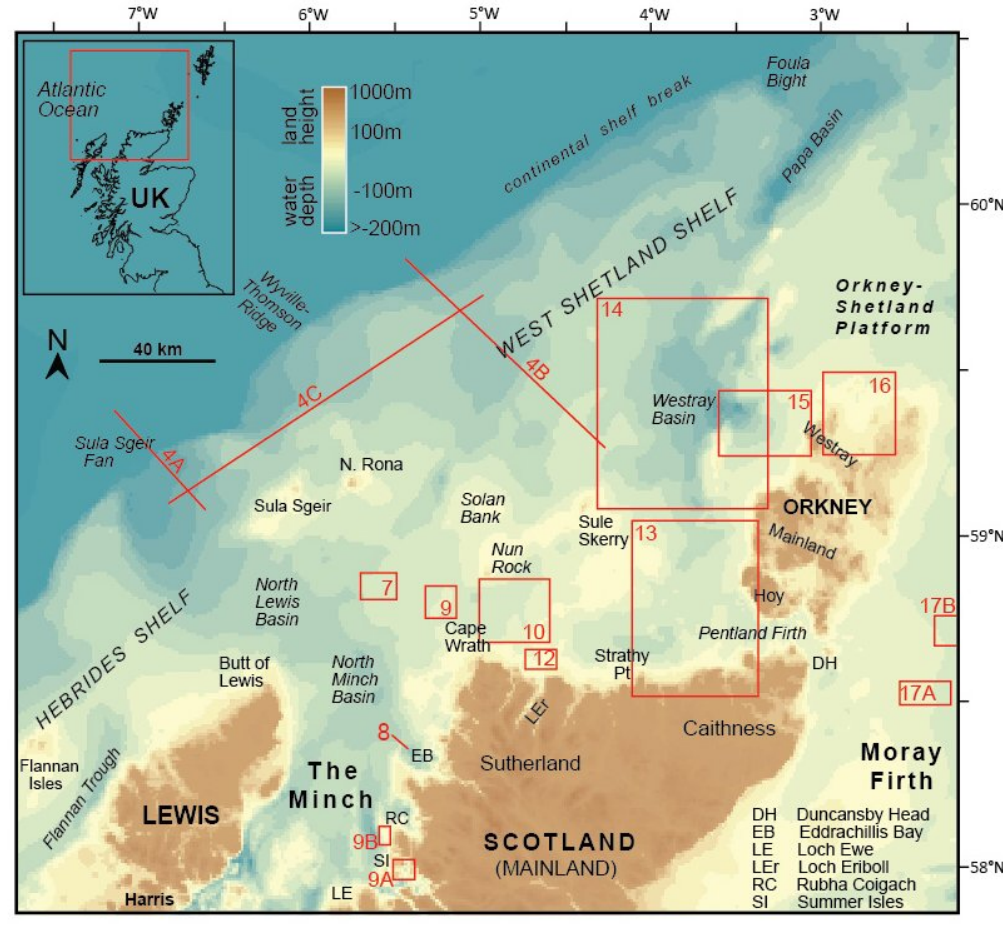




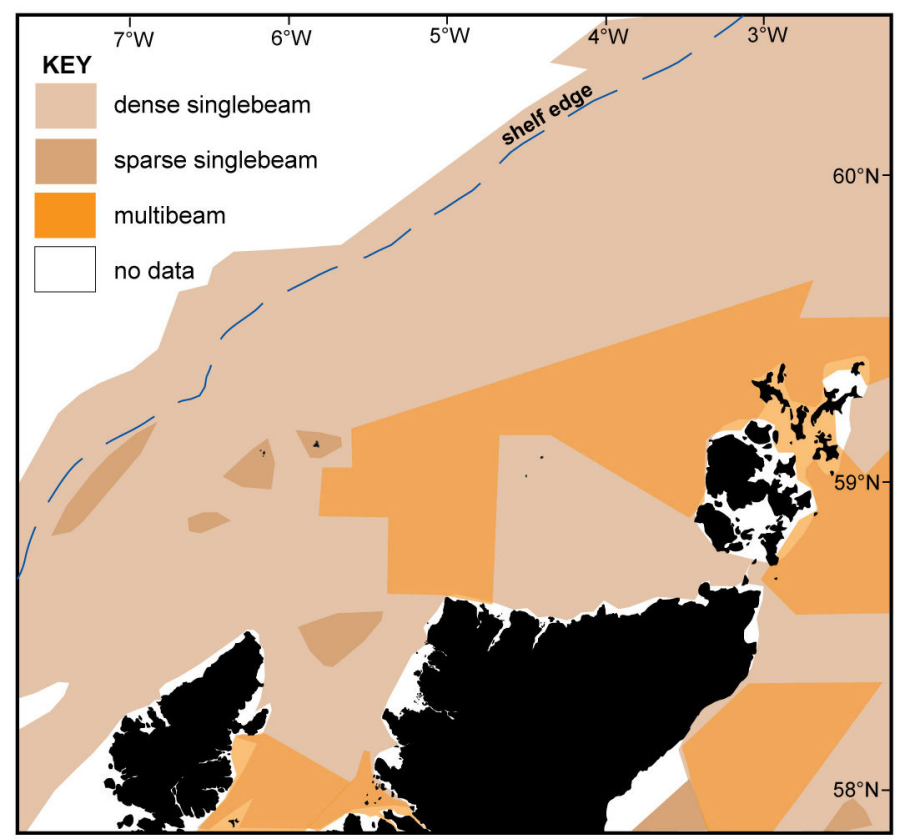




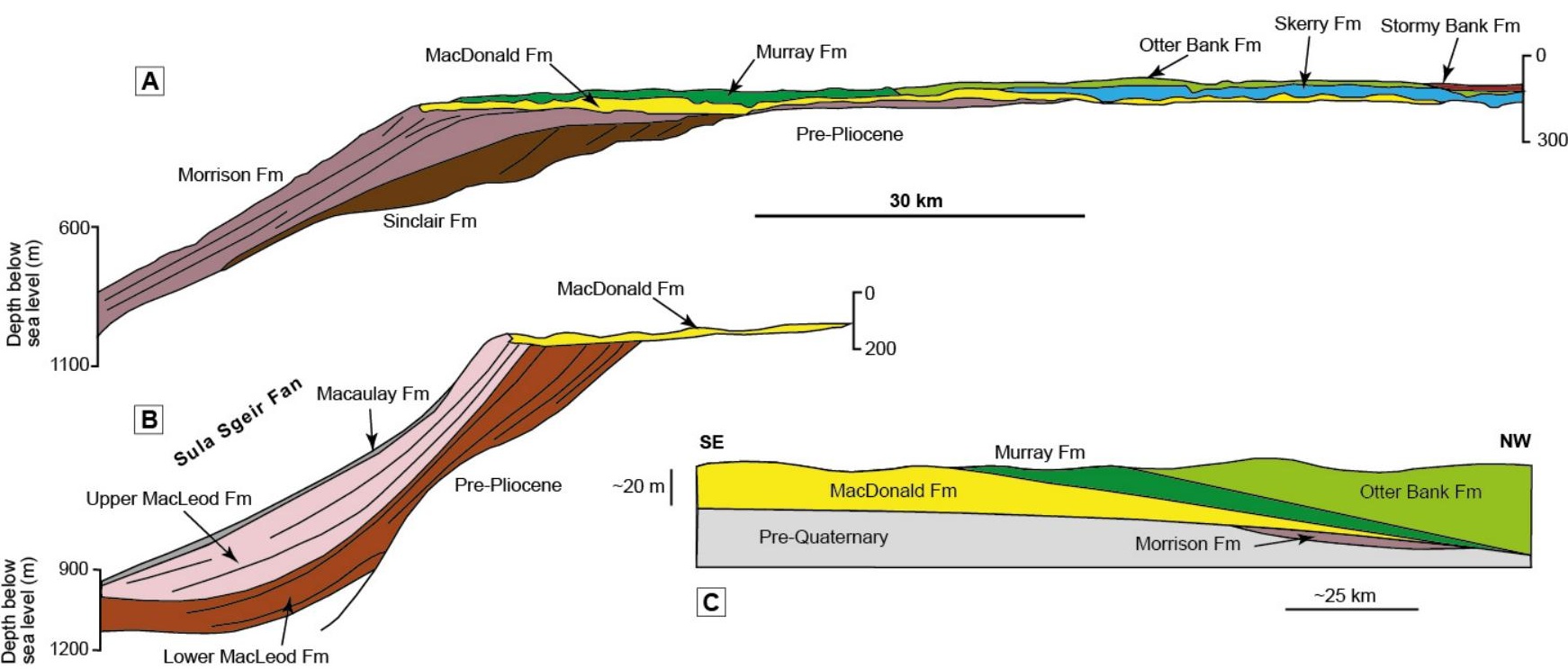



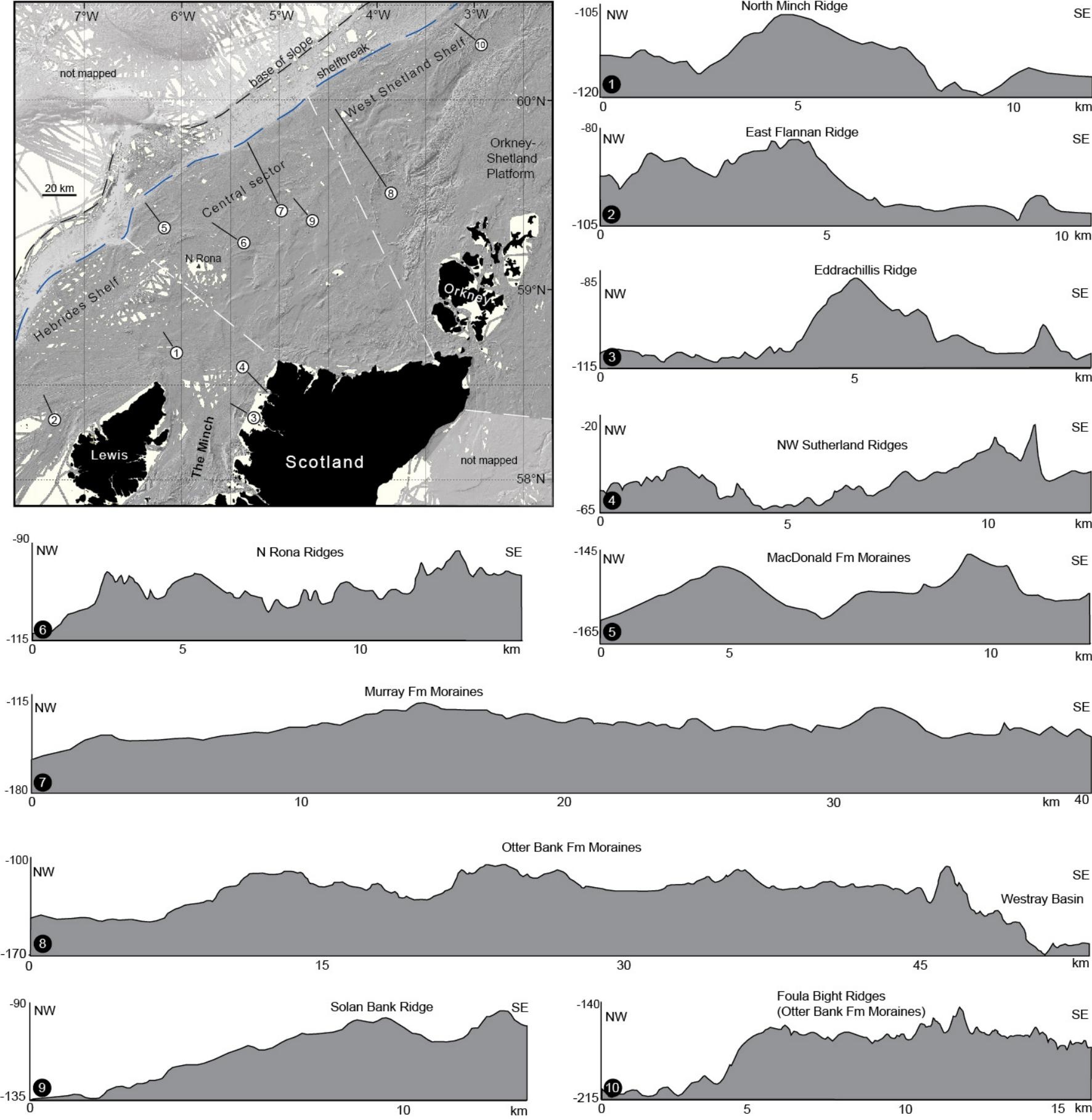


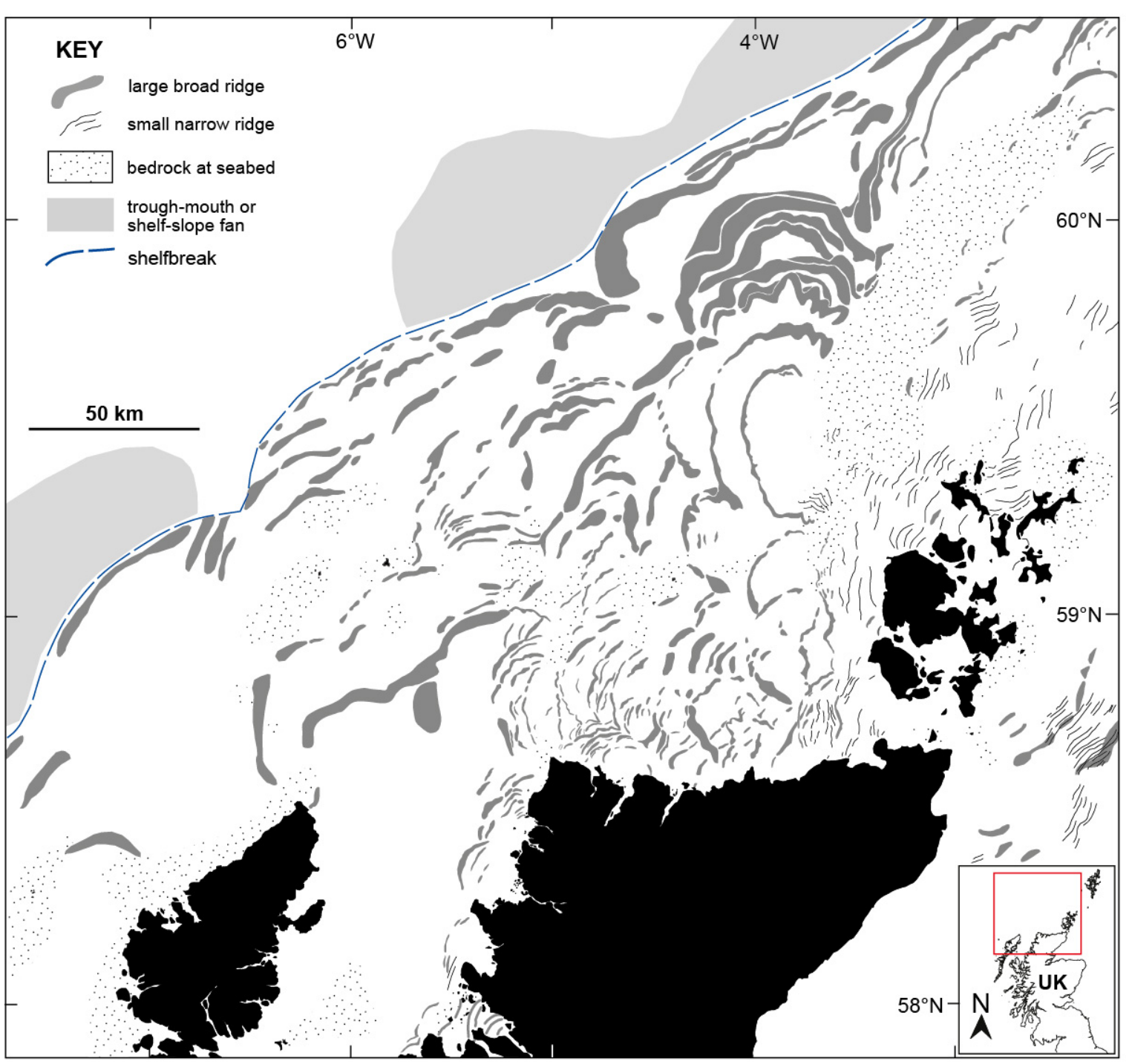


A

$1 \mathrm{~km}$
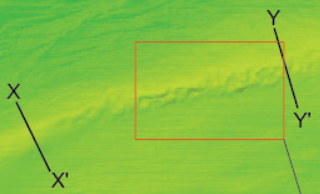

m

120

B

-80 X

$-86$

$-82$

0

1000

2000

$\mathrm{m}$

$-74$

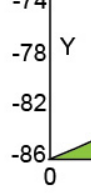



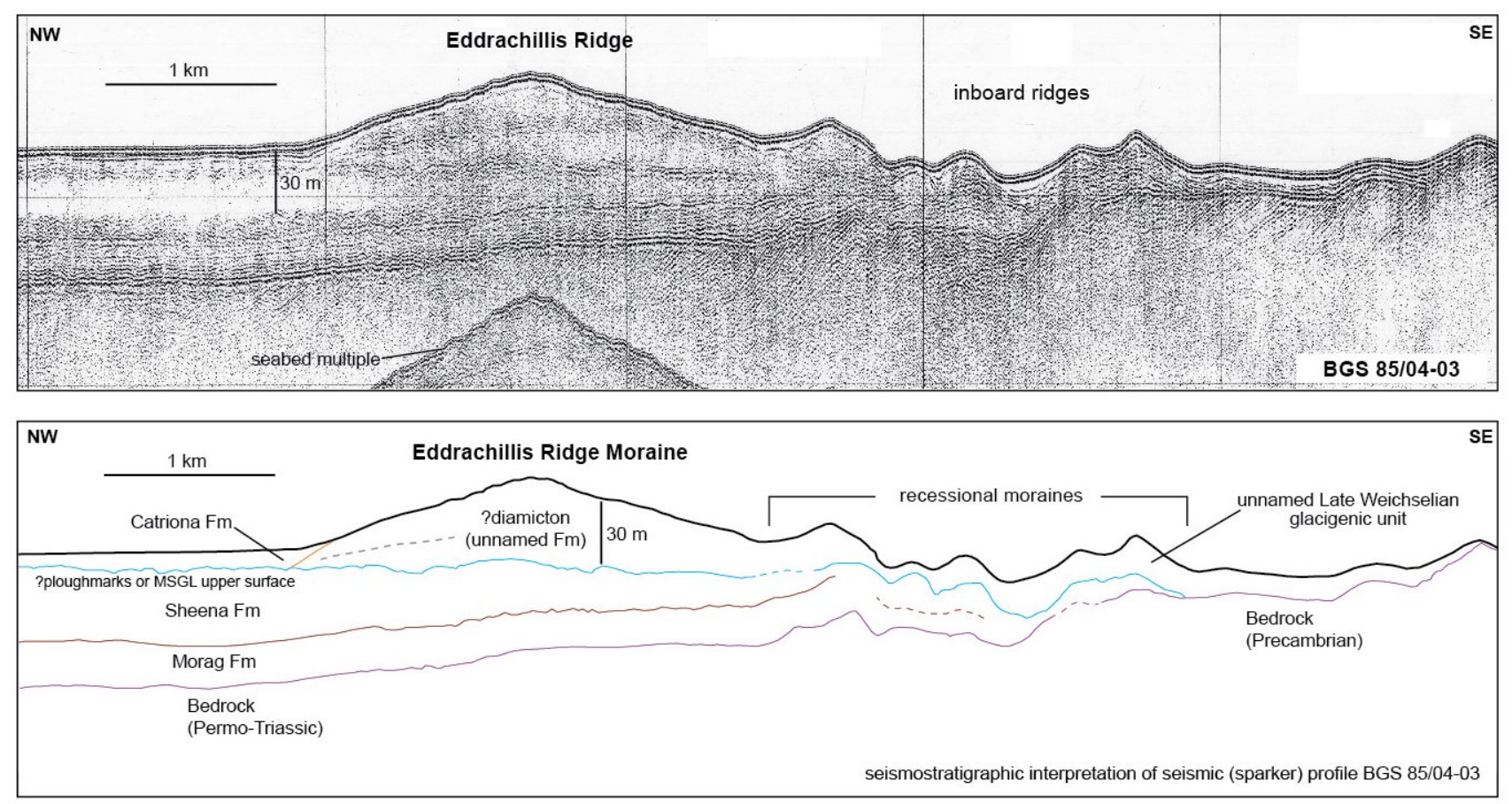


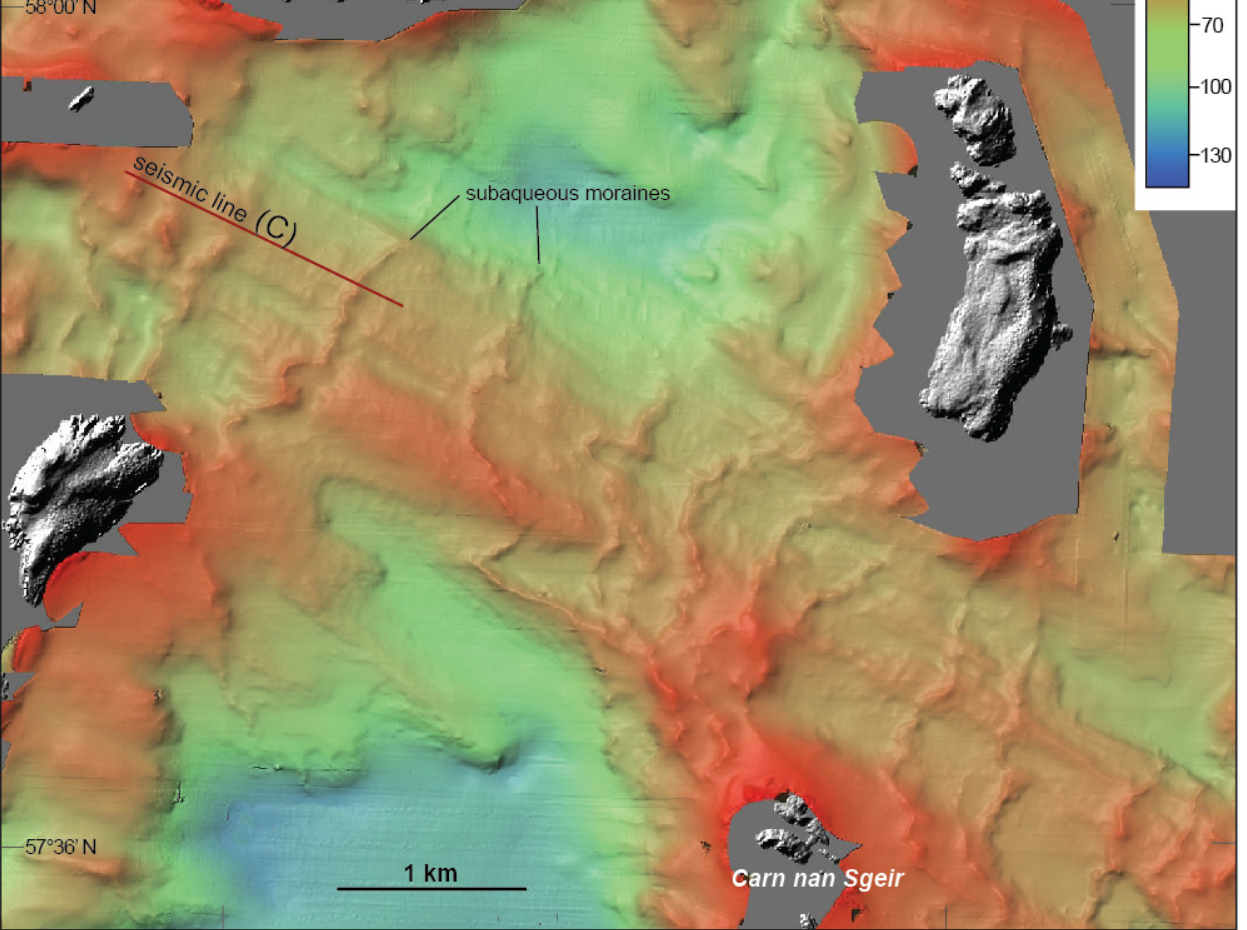

C subaqueous moraines

\begin{abstract}
हो)
\end{abstract}

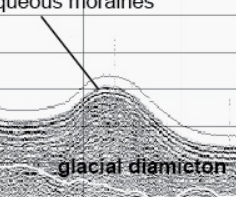

rockhead? ESE

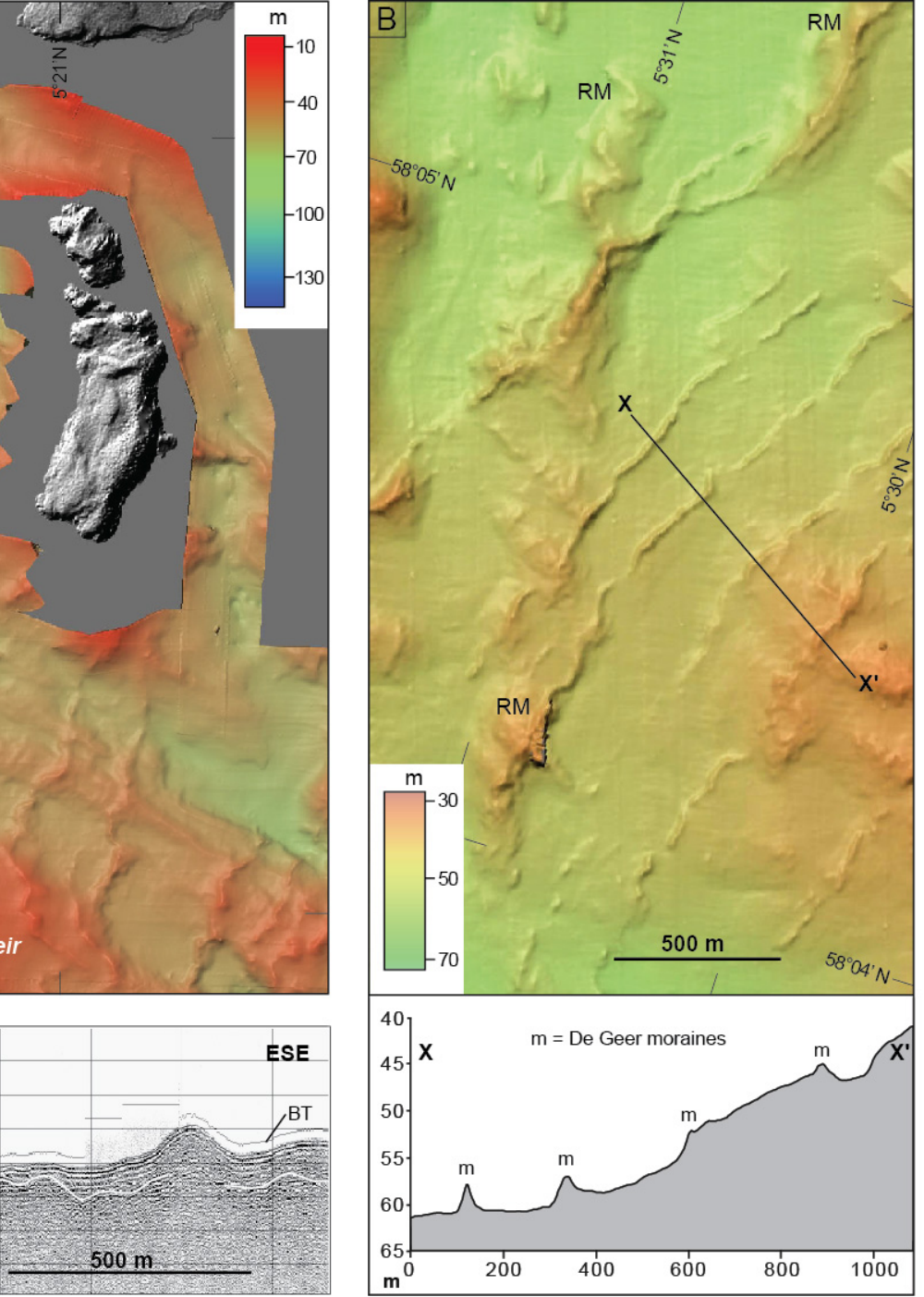




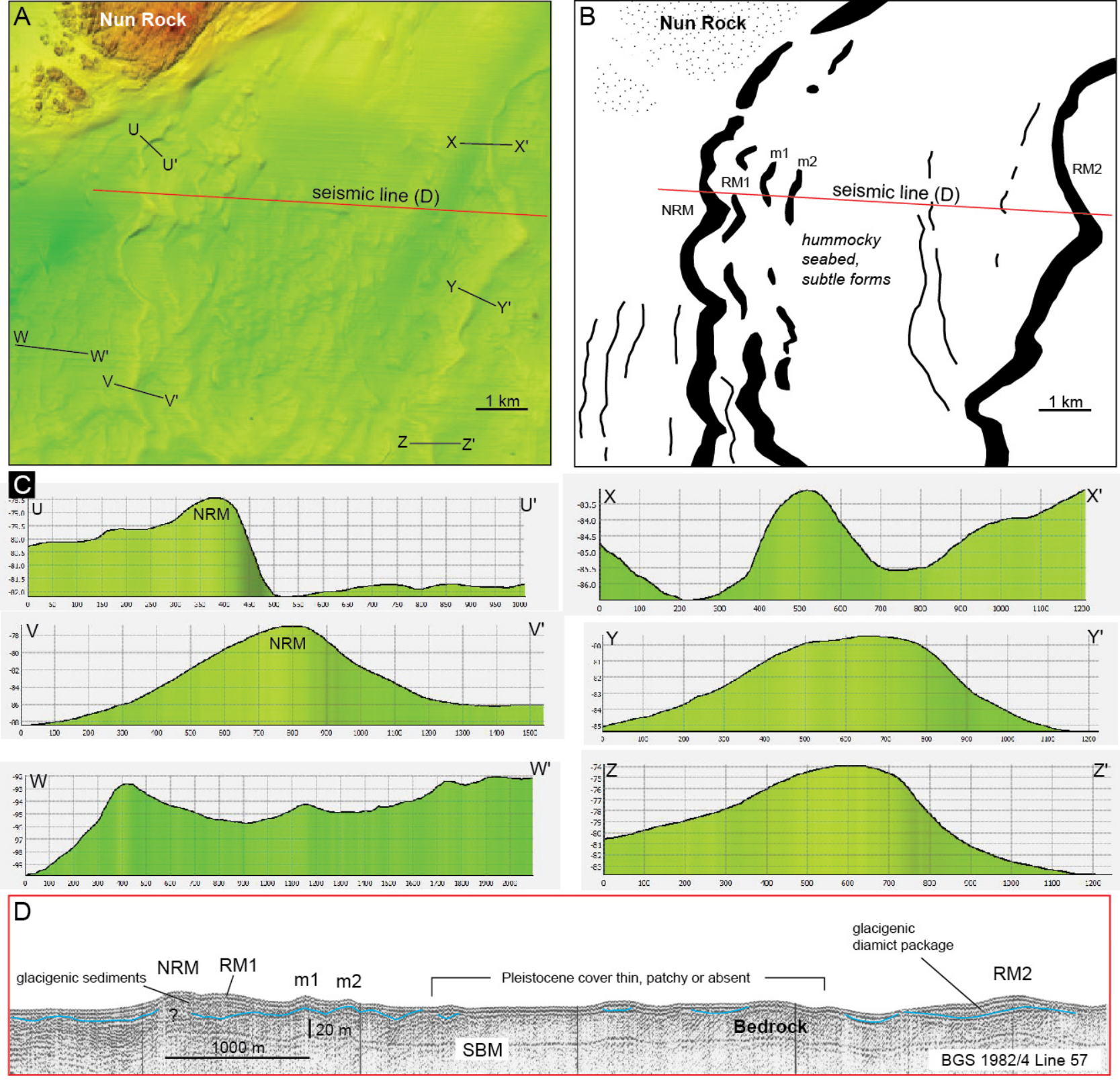




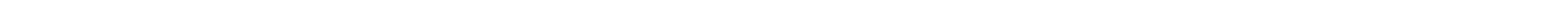



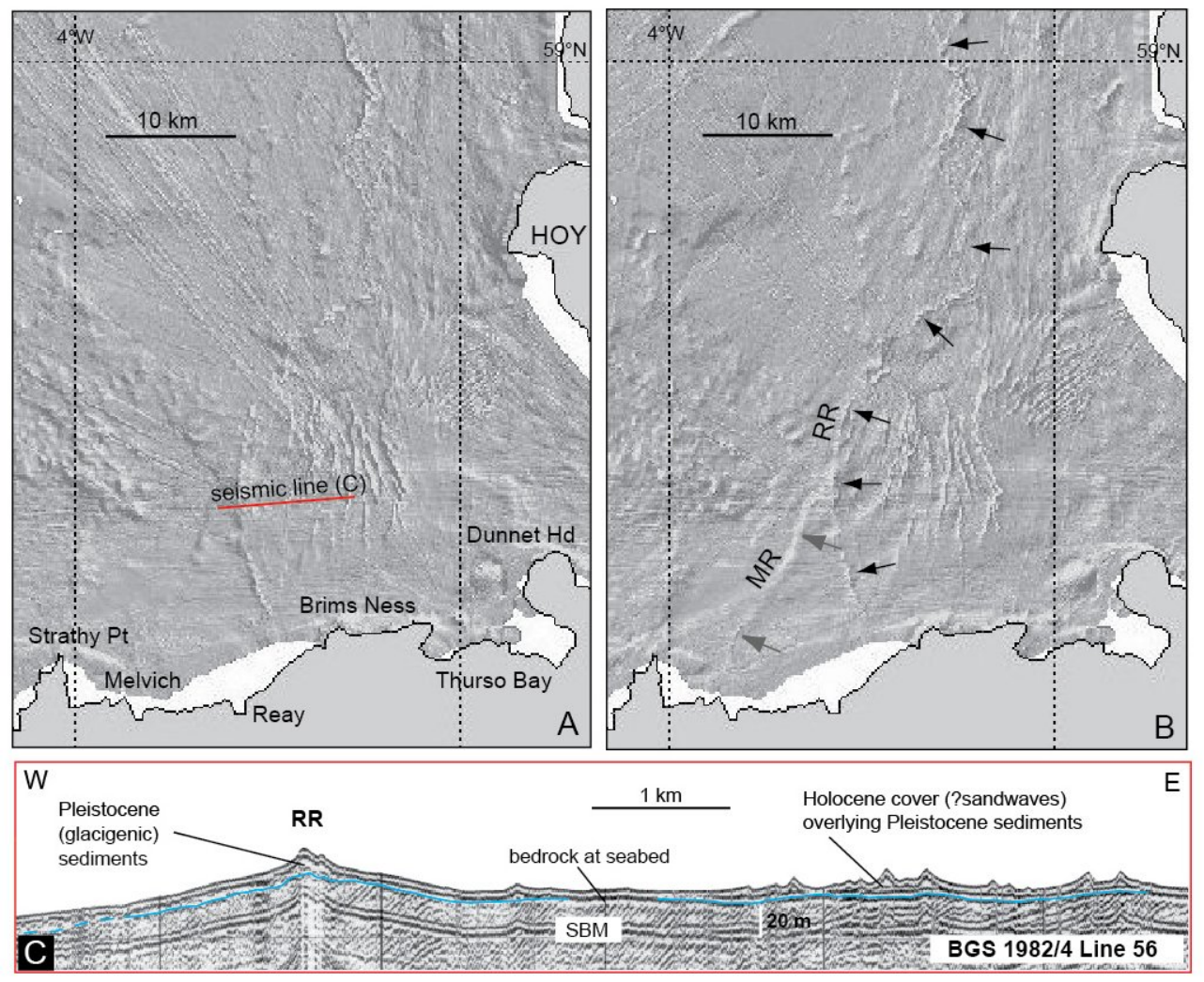

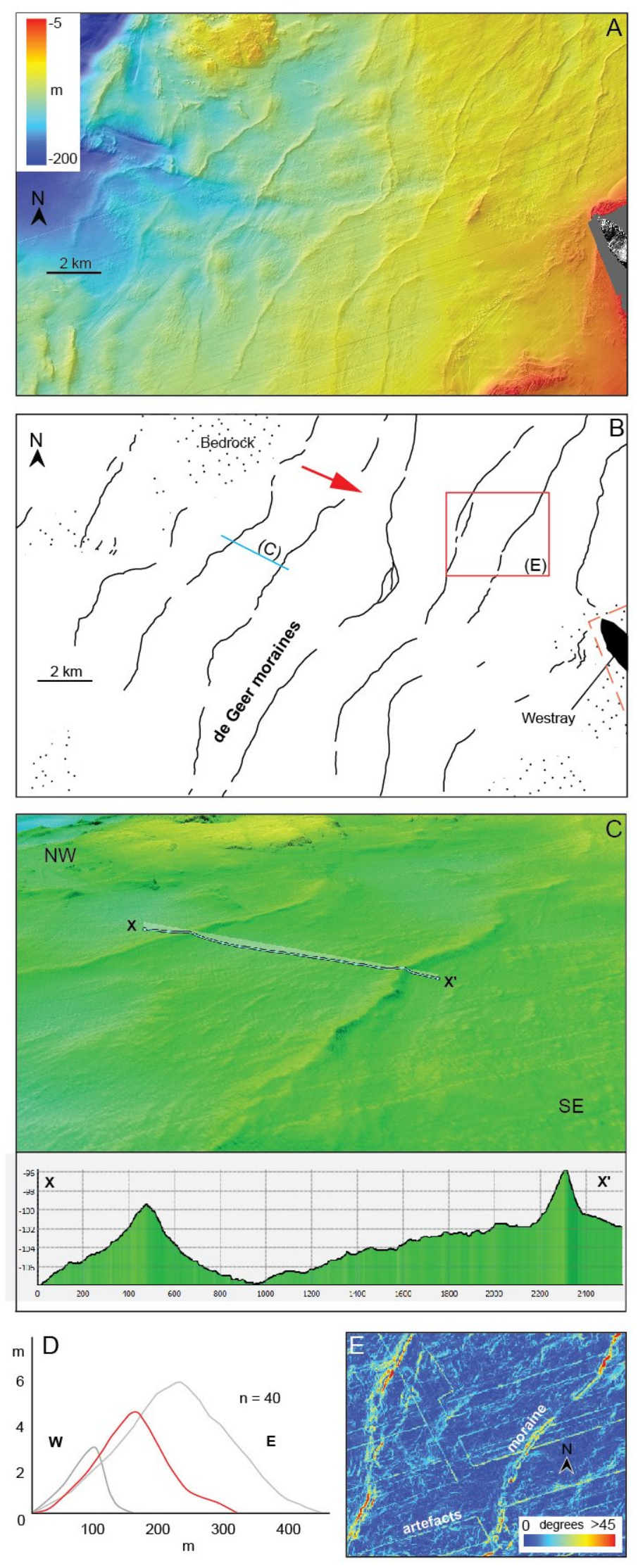


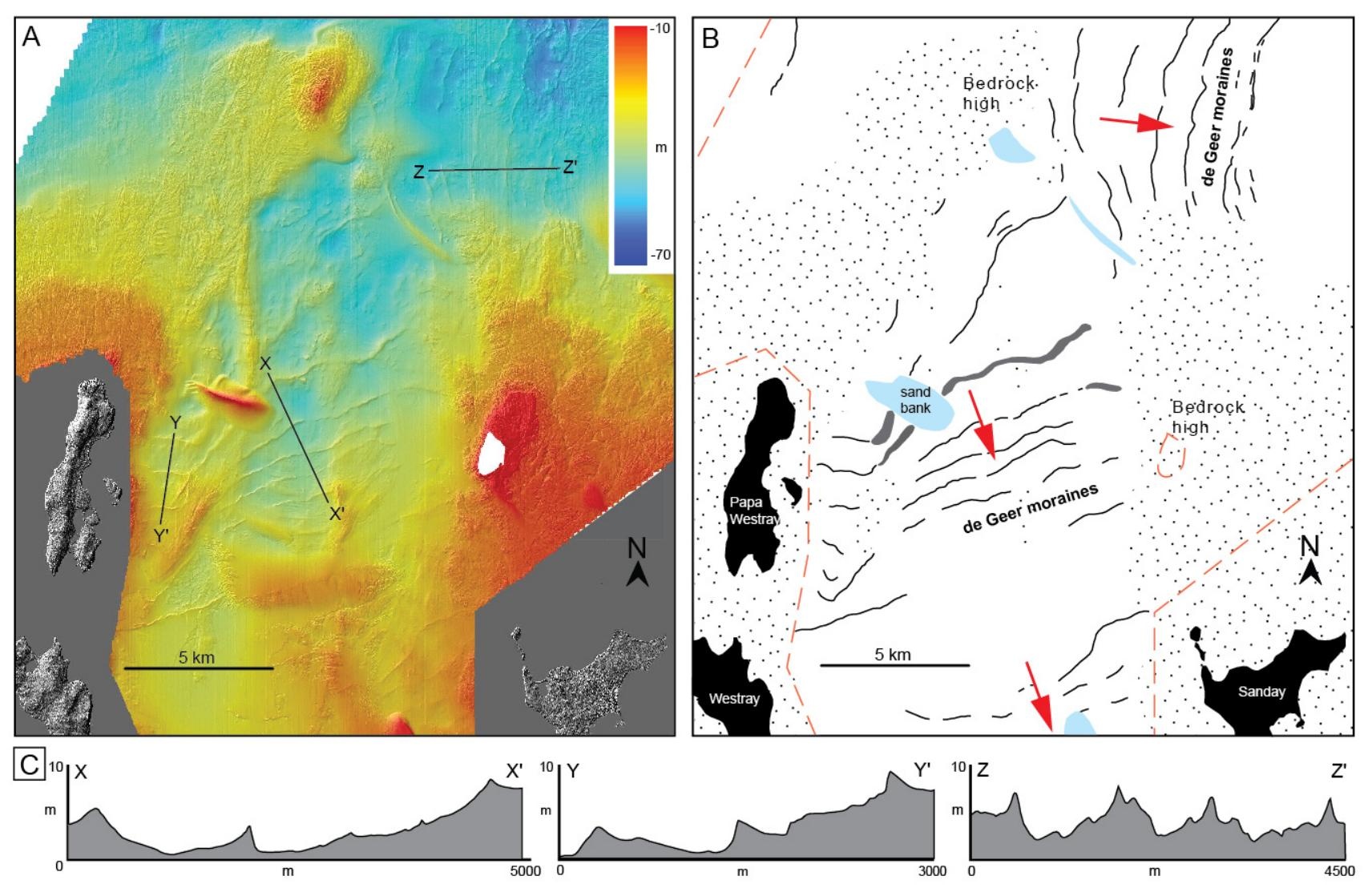




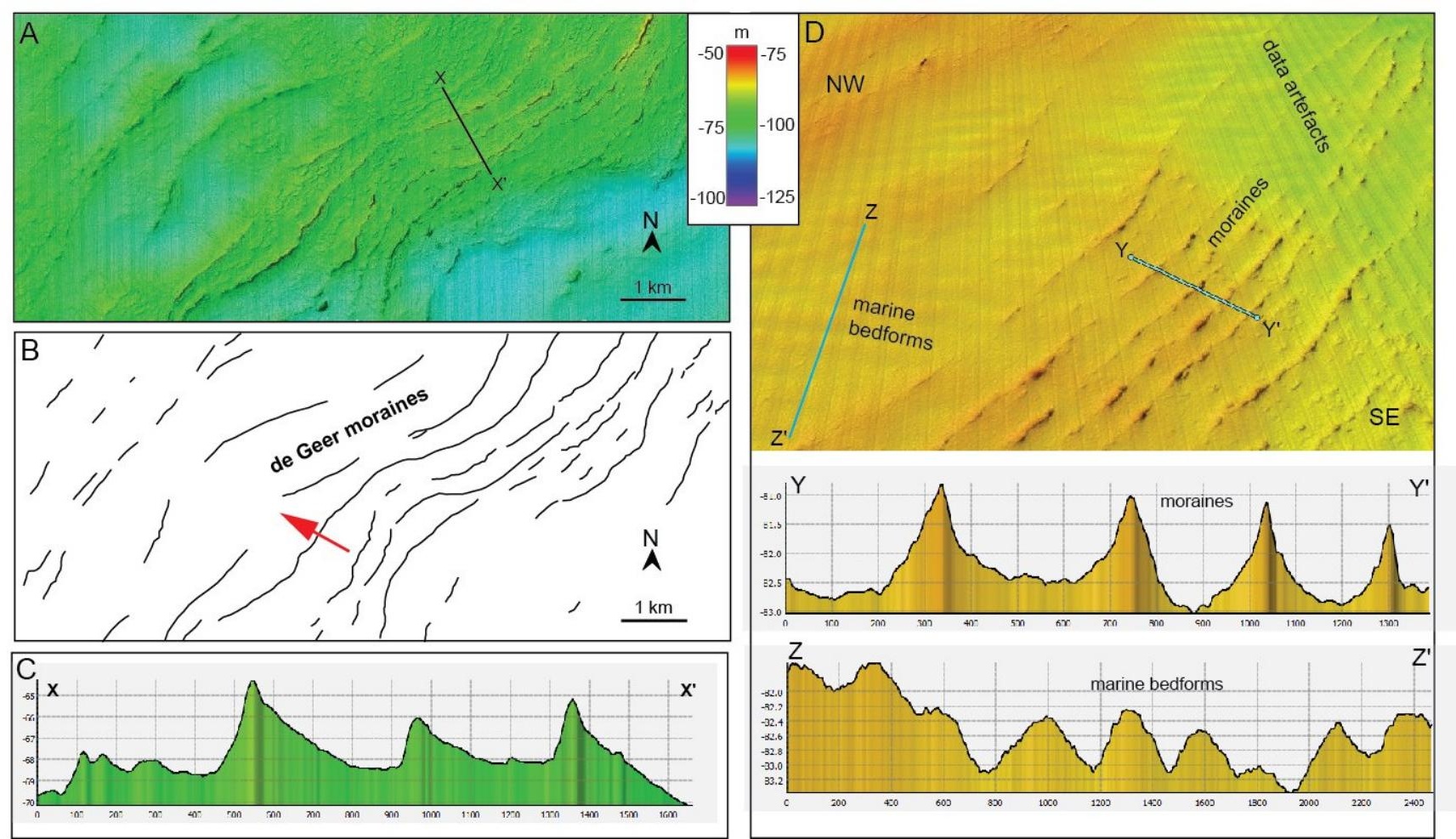




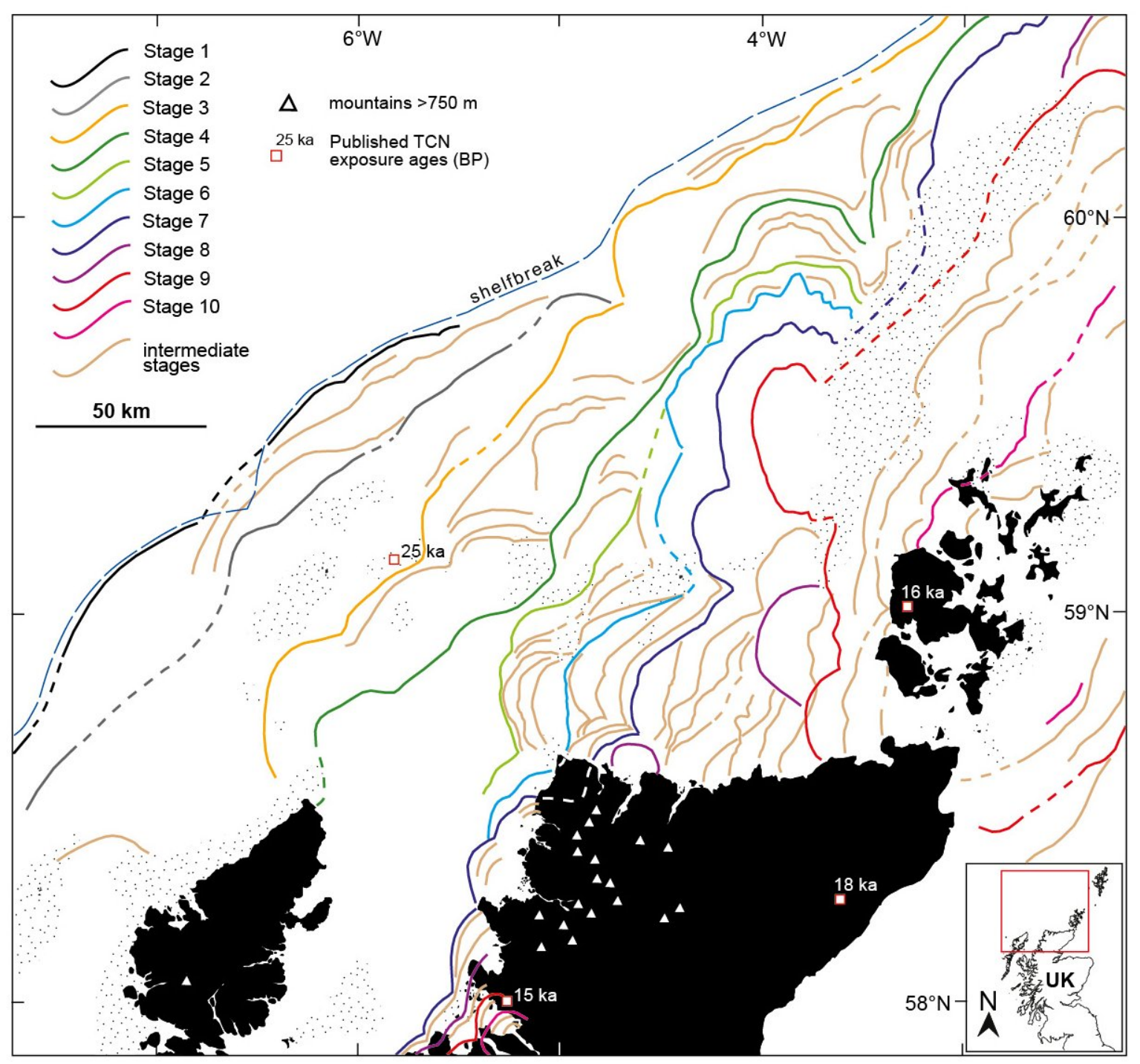




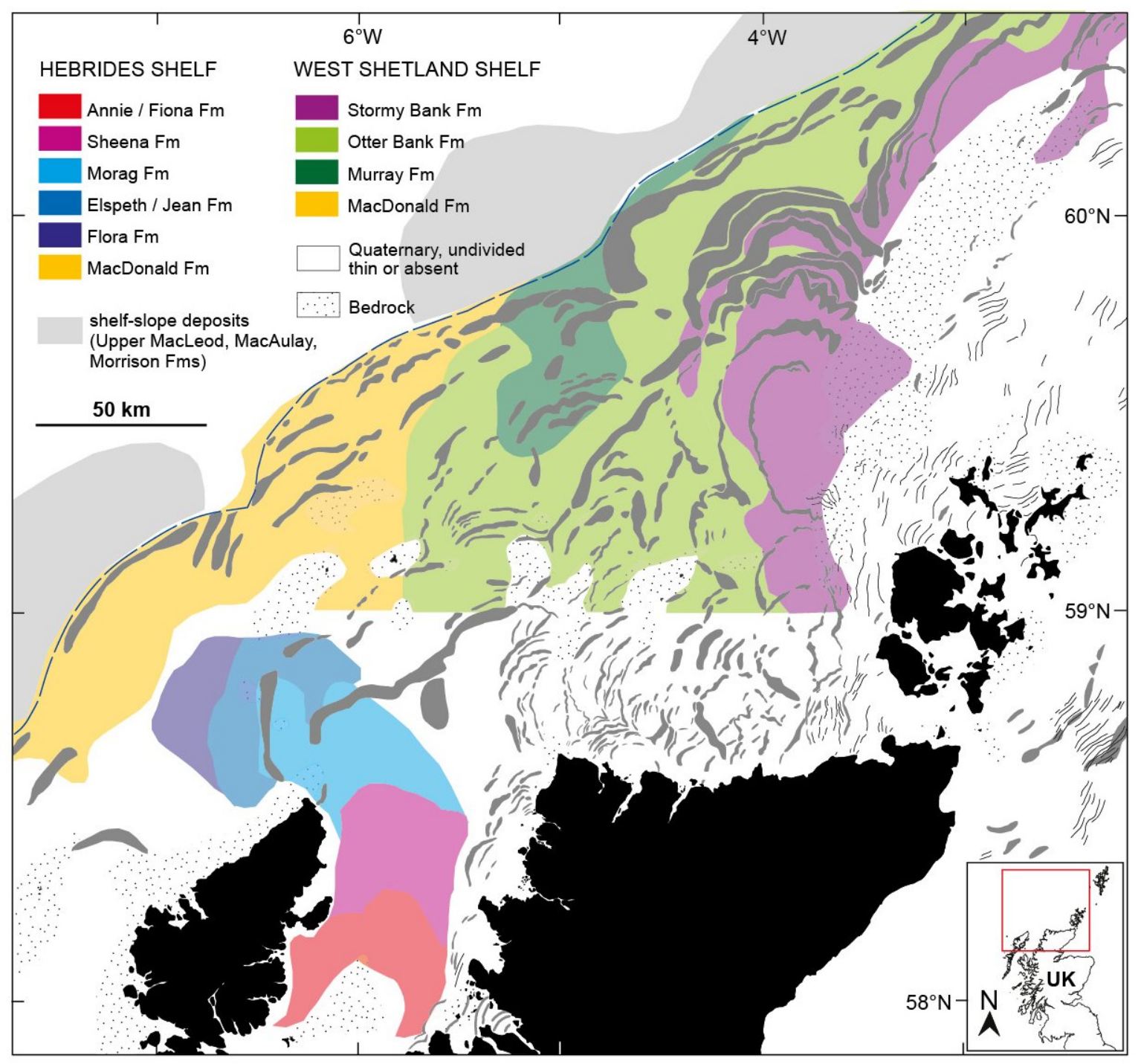

